\title{
Incentives - their value and accountability in business attraction and retention: the debate continues
}

\begin{abstract}
David C. Paul, Ec.D.
Varied approaches to incentives for investment attraction and business retention have been developed in communities and regions throughout Canada and the United States. Yet, there still remains debate on effectiveness and accountability of incentives by the economic development profession, the service provider and the corporate end users. This paper provides an overview and assessment of incentives in Brockville, ON, viewpoints from economic developers, corporate executives and consultants, a comparative analysis between Canada and United States, preferred incentives by corporations, trends and perceived importance of incentives, accountability and justification issues, and future influencers. The consensus is that incentives have a role of growing importance in the site selection process, despite some fluctuation in the rankings in the annual surveys on the subject. But the real debate focuses on the accountability and justification factors associated with incentives. It is suggested that governments and organizations develop better tools for project analysis and improved tracking, accountability and justification.
\end{abstract}

Keywords: incentives, investment attraction, business retention, Canada, United States

\section{Introduction}

The topic of this paper, the role of incentives in both the investment attraction and business retention in economic development, was prompted by at least five events over a period of three years.

The first activity was Brockville's effort to secure the status as one of the six pilot communities or regions under a tax incentive zone program being proposed by the former Ontario Conservative government. A change of government quickly terminated this initiative.

The second event was the escalating marketing and communications from our American neighbour in Ogdensburg, New York, on the promotion of their no tax-no kidding campaign targeted at Eastern Ontario industries. Direct solicitation and visitation was part of the process. This jurisdiction is approximately 20 minutes from Brockville, being part of both the Empire State Enterprise Zone as well as a Foreign Trade Zone.

The third activity was my first exposure to aggressive site locator requirements for incentive offerings as they related to establishment of contact centres in Eastern Ontario. This period from 2002 to 2003 generated 14 contact centre prospects seeking, during the preliminary search, significant levels of incentives and related concessions prior to being considered for the second 
stage of short listing communities. One American firm requested a five year holiday on property taxes before considering the other attributes of our community.

The fourth event, and likely the most frequent, was the increasing request from our own existing multi-national firms seeking concessions from all three levels of government to effectively compete for the retention of existing product mandates and to secure new opportunities. The project that consumed most of our energy was the Brockville site of Procter and Gamble. This firm, trying to compete to retain their dry soap business unit was facing major competition from two American sites in Georgia and Louisiana. Both offered generous financial incentives. The final chapter of this process resulted in the entire business unit going south. The Brockville site, however, was successful in securing two new major product lines for the company which represented the fastest growing business units in terms of volume in all of the Procter and Gamble products. One significant concession that Procter and Gamble noted as critical to this outcome was a lowering of the ratios of the industrial and commercial classes, resulting in a 47 percent decrease in taxes for industrial companies. This was accomplished by shifting the tax burden to residential and applying the proceeds from the sale of the local utility towards the overall tax structure, thus providing a positive outcome for all classifications. This action provided further positive outcomes from a number of other local industries as they collectively contributed up to 15 percent of their individual tax savings for each of the next three years towards the extension of the municipal airport, thus enabling jet capacity. This represented a $\$ 200,000$ contribution towards a special economic development project touted as a necessary tool for future growth and retention activities.

The final and most recent event involved our mayor. He was becoming increasingly more frustrated with the lack of tools to close deals on both investment attractions and the retention of existing firms. Brockville lost 1000 industrial jobs in 2002, representing 20 percent of the industrial workforce, and all the overtures to upper tier governments for assistance were not being acknowledged. His statements that he would do whatever it takes to attract an industry and close a deal received national coverage and certainly reflected his passion and desire to go beyond the norm for the economic health of his community.

Collectively these events prompted a desire for more in-depth analysis of the incentive process. It became apparent that incentives are being utilized in a different manner amongst jurisdictions. Varied approaches have been developed in communities and regions throughout Canada and the United States. There still remains debate on effectiveness and accountability of incentives by the economic development profession, the service provider and the corporate end users.

This paper will provide an overview and assessment of the following:

- An historic overview of incentives in Brockville

- Viewpoints from economic developers, corporate executives and consultants

- Comparative analysis between Canada and United States 
- Preferred incentives by corporations

- Trends and perceived importance of incentives

- Accountability and justification issues

- Future influencers

\section{Historic context of incentives}

Incentives, or the more common term, bonuses, were a very common investment and retention tool utilized by Ontario communities and their Boards of Trade in the late 1800's and into the early 1900's. The practice lost its legal sanction under Provincial law in 1924. ${ }^{1}$ To demonstrate the outcomes of this practice, several examples are provided from accounts of Brockville's robust industrial development during this period.

In 1890, Brockville was the 17th largest urban centre in Canada in terms of population. It was an important regional commercial centre, possessing both a rail and water port. The location on the St. Lawrence River represented a significant business attribute, as it does today. It shares a border with the United States and is a midway point between Toronto and Montreal.

To provide the impetus for industrial growth, the community established a Board of Trade in 1890. The Board was to be the advisory committee to the Town Council on providing direction and due diligence on the viability of granting bonuses to certain firms seeking the concession to relocate to Brockville and in later years, to remain in the community. It was realized shortly after inception that the usual non-monetary promotional virtues and welcoming hand of the community was insufficient to close the deals. Other Ontario communities were getting into offering bonuses to attract the same firms seeking new locations. Bonuses soon became a common and accepted practice.

Gifts of money and land were the most common form of bonussing, with the prospective firms being required to fulfill certain conditions for these community concessions. The first recorded bonus approved by the Town Council was for a tool works proprietor. This company received a site valued at $\$ 4500$ and a ten year exemption from municipal property taxes. The factory was established and created the required 40 to 50 skilled jobs as part of the firm's obligation.

The next bonus was for the retention of the town's largest firm, the James Smart Manufacturing Company, with a workforce of 200. The firm was being pursued by Toronto, and was offered significant financial assistance to relocate there. The town reacted with the offer of a $\$ 10,000$ bonus and a ten year tax exemption. The company was retained. Shortly thereafter, the company undertook a major expansion and remained active for more years.

The offering of a bonus did require a specific process to be followed, as mandated by the Province. The community was obligated to conduct a referendum with approval of at least $2 / 3$ of

\footnotetext{
${ }^{1}$ Richard Faulkner, Brockville A Social History 1890 to 1930, Waterway Press, Brockville, 1975.
} 
the eligible voters. The granting of bonuses generally was well received by the voters for about 15 years. There was some disillusionment with the bonus offering by some of the town councilors. This was the result of some companies not meeting their obligations to the town, and in at least one example, closing operations. More attention was directed towards securing hydroelectricity as a more strategic and longer term approach for sustainability. There were firms attracted to other communities who continued to offer the bonus after Brockville ceased this practice.

Not all request for bonuses were granted. The role of the Board of Trade was to determine the level of and justification, was granted in 1921 to the Eugene F. Phillips Electrical Works Ltd. based in solvency of companies requesting concessions and the potential impacts to the community. There were debates between the Board and the Town Council over priorities. Additionally, there was reluctance from the voters who were advocating changes in the bonus provisions and in the criteria for qualifying firms for the municipal concessions.

The types of bonus offered became more creative during the last few years in which the process was legal in Ontario. For example, the town bought property and provided rail siding to the site for one prospective company. Servicing and the offering of incidentals such as building materials also became part of the agreement between the town and the company.

The last and most significant bonus, and the one with the greatest level of accountability Montreal. Their obligation was to completely relocate all their operations to Brockville and create 185 jobs. The town of Brockville provided the following:

- An $\$ 80,000$ bonus

- Provided property well below market value at $\$ 20,000$

- Constructed road to site at a cost of $\$ 80,000$

- Extension of all services at a cost of $\$ 77,000$

- Supply of bricks from the community brickyard

- Taxes at fixed assessment of $\$ 20,000$ for ten years

The deal was a good one and generated a remarkable return on investment, including the following:

- The firm remained in business for 75 years

- It employed up to 2000 during its peak period

- Contributed $\$ 800.000$ in annual property taxes in the later years of which made this firm one of the highest corporate taxpayers in Brockville

- Procured ten million dollars annually in products and services from regional businesses

- Saved the community $\$ 19,000$ annually in hydro electricity cost since the firm planned to purchase 1,100 horsepower of electricity, and as such, spread the costs of transmission to the town over a greater number of horsepower. 
- The extension of municipal services to the plant site facilitated residential development in the west end of the town

- Phillips was a major contributor to charitable campaigns and provided a strong volunteer base for the community

Bonuses generally worked well for the community's investment attraction. They were touted as preventing serious decline in the town's industrial base. There were bad deals, however, lessons were learned and changes made to the obligation criteria thereafter. The Board of Trade played an important role in the process and provided guidance to the town council on the viability of the various proposals for bonuses.

The use of incentives was also utilized in the United States. Massachusetts, New Jersey, Georgia and other states courted business with incentives to spur growth in their underdeveloped economies. During the Great Depression years Mississippi and other southern states solicited out-of-state businesses with offers of generous tax relief and ample public capital. Following World War 11, tax revenues swelled, state governments expanded and politicians used incentives aggressively. By 1963 there were 19 states active in the incentive game. ${ }^{2}$

\section{Survey says}

Prior to commencing this paper, I knew through informal discussions at various international economic development conferences that there was a difference of opinion between Canadian economic development professionals and their American counterparts on the subject of incentives. Additionally, viewpoints expressed during a consulting mission to North Wales in 2004 prompted further assessment of incentives, their impacts, usefulness and importance at the various stages of the investment attraction or retention process. There is no real consensus on what is the right incentive for the right jurisdiction, the right amount or the right firm. It was necessary to complete primary research, utilizing both an electronic survey tool and personal interviewing to provide a more current assessment of the role of incentives in economic development.

\section{Survey methodology}

A survey template was developed encompassing four questions with a short preamble and description. The questions were as follows:

- What incentive offerings do you provide?

- Have incentives assisted you in your site location process?

- Do you consider incentives a primary tool in the past three years?

- Are incentives becoming more or less important in the site selection process?

${ }^{2}$ Chris Farrell, The Economic War among States, Business Week Commentator, Minnesota Public Radio, May 1996. 
The Economic Developers Association of Canada, the Economic Developers Council of Ontario and the Ontario East Economic Development Commission were utilized to seek responses to the survey from their respective memberships.

Supplementary, personal interviews were conducted with Economic Developers, Service Providers and Corporate Executives at two international economic forums, namely the Industrial Asset Management Council conference in March 2005 in Charleston, North Carolina, and the Toronto Cornet Global Summit in April 2005. Twenty professionals were approached for commentary on the subject, utilizing the same survey format to initiate discussion. The composition of interviewees represented an equal split between Canadian and American practitioners. No service providers or corporate executives were included as I felt the nineteenth annual 2004 Area Development Survey provided a good, comprehensive assessment of their respective viewpoints on the subject.

\section{The findings}

The 49 electronic responses from the both the provincial and national development associations confirmed that the five most frequently offered incentives in Canada were low cost industrial property, no development charges, job fair hosting, tax concessions and permit fee waivers (see Figure 1.) $)^{3}$ There was no significant difference in this ranking profile amongst the membership responses from the various provinces.

Secondary in importance and utilization were a myriad of incentive packages of upper tier government programs intended to stimulate economic growth and prosperity. Labour force and human development initiatives were the most frequently noted, with research and development tax credits and subsidies identified in specific cases. Commentary from developers stressed that the creation of a pro-business environment in the community was as important as the incentive itself. The fast tracking and commitment of the legal compliance process associated with a development would generate a long term return on investment and establish a sound foundation for future negotiations.

\footnotetext{
${ }^{3}$ Economic Developers Survey, March 2005.
} 
Figure 1. Type of incentive

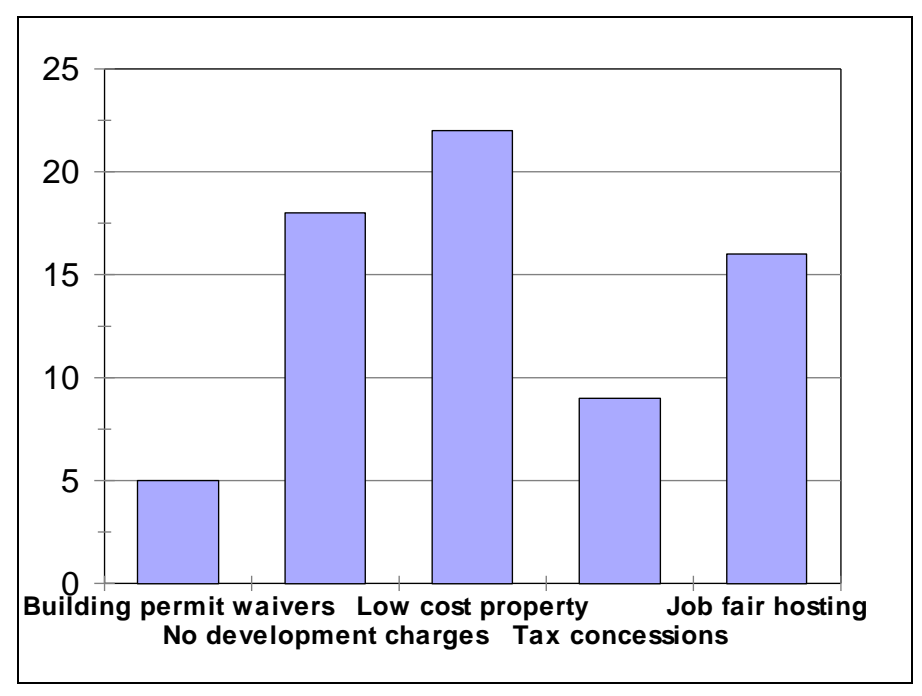

Source: Survey data, 2005

The survey confirmed that incentives assisted Canadian communities in closing deals with 60 percent of the respondents confirming satisfaction with their usefulness in the process (see Figure 2). The response from American developers who were personally interviewed was unanimous in supporting the essential role of incentives in site selection. In fact, KPMG Peat Marwick noted in a 2004 survey of over 200 manufacturing, retailing and distribution companies that 73 respondents indicated they were more likely to be offered incentives now than during the previous five years. ${ }^{4}$

\section{Figure 2. Incentive importance in site selection}

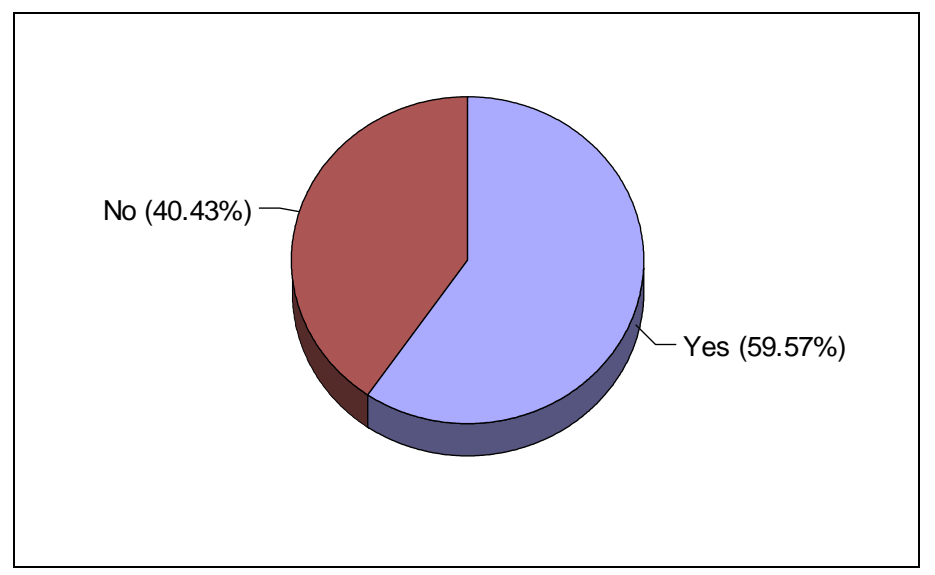

Source: Survey data, 2005

${ }^{4}$ Chris Farrell, The Economic War Among the States, Business Week Commentator, Minnesota Public Radio, May 1996. 
The response to the question on incentives as a primary tool demonstrated further polarization of the subject with 40 percent agreeing with the importance of the incentive tool, 55 percent feeling it was less important and the balance with no comment or opinion (see Figure 3). Again, American developers continue to tout the virtues and their growing importance. The Area Development survey of service providers and corporate executives agreed with the trend towards incentives being a more important tool in site selection. This is elaborated upon later.

Figure 3. Incentives as a primary tool in site selection

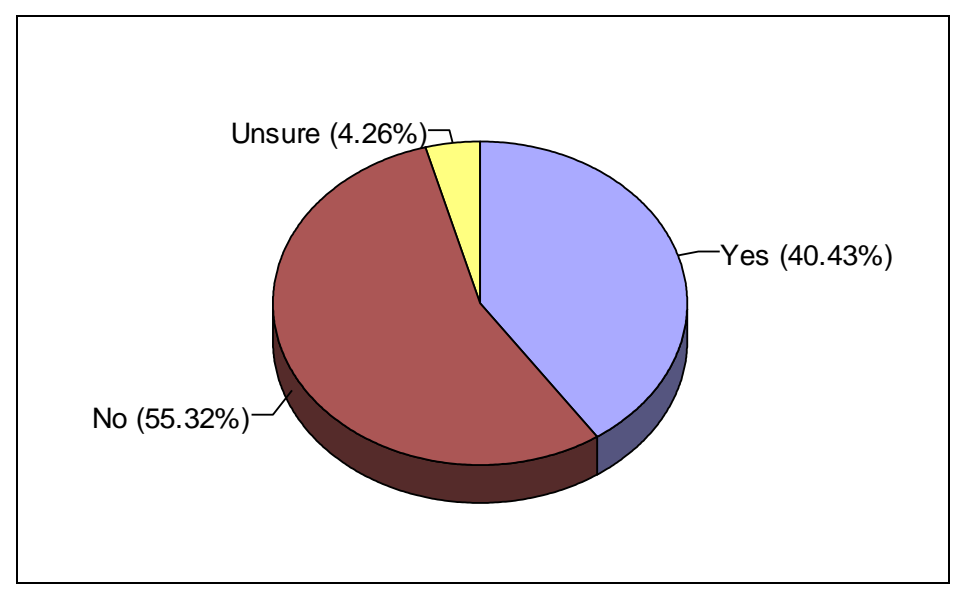

Source: Survey data, 2005

The profession was more in agreement with the idea that incentives were growing in importance, with 59 percent agreeing with this statement, 25 percent considering incentives less important, with balance with no opinion (see Figure 4).

\section{Figure 4. Importance level of incentives today}

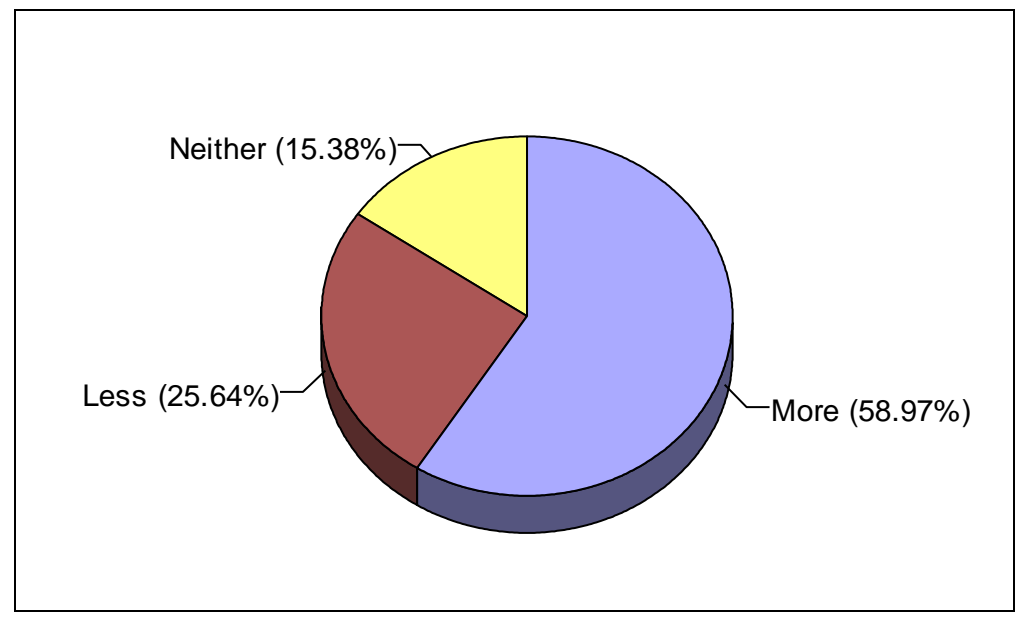

Source: Survey data, 2005 
The comments offered in both the electronic surveys and the personal interviews capsulated the divisions amongst professionals on the subject and confirmed that this debate continues. The elements of the debate are focused on the degree of importance of the incentive, the time when the incentive should be introduced, their justification and the economic impacts for public and private sectors. Some of the specific arguments which support this statement include the following:

- $\quad$ "Local economic development should not provide awards to preferred firms only. Communities should create a general business climate conducive to economic growth."

- "For some sectors and jurisdictions the incentives have often become part of the opening of the deal as opposed to the way to close a deal."

- "Incentives are important when they impact investment cost, operating cost and as such, can differentiate geographic locations."

- "The fundamental basics of site selections, including labour cost, energy, telecommunications, human resources and the supply network, must be satisfied prior to the due diligence of incentive offerings."

- "It is important to know how a firm negotiates incentives so as to be more successful in reaching a compromise on a satisfactory outcome for both parties."

- "Assessment of value by the firm is the primary task associated with site selection."

- "Incentives are more aggressively utilized by American communities than in Canada. It is more integrated into their process."

- "Canada is in a catch-up mode on incentives."

- "Canada shines on non-monetary incentives associated with labour attributes which represents a more long term success formula."

- "It is important for the provider of the incentives to ensure taxpayers money is spent wisely."

- "Incentives are a marketing tool to strengthen the economic viability of an area and help to achieve the community's mission statement towards wealth creation."

- "Incentives should be utilized as an aid for controlled growth."

- "Incentives help sway site location decisions, they close deals, they mitigate business risk and they demonstrate a willingness by the community to present a positive business environment for future development."

- "A general overview of incentives should be noted during the initial promotion of the community or region to assist the site selector with the preliminary screening which ultimately is the de-selection phase of the process."

- "Work force education and training is the most desirable long-term feature of incentive programs."

- "Fiscal incentives are enhanced when combined with other measures." 
- "Canadian firms consider incentives more as "icing on the cake" and are highly unlikely to make them the focal point of a location decision. The icing is less appealing if the cake beneath does not taste good."

- "An incentive should be credible in the sense that it is irrevocable with a change in government or a change in policy."

- "Incentives have little to do with foreign investor attraction but more are effective when dealing with the relocation of smaller firms from within Canada to other parts of Canada."

- "Ontario has been most successful in competing for investment without incentives and in particular with site selection assessments with border American states."

- "Incentives are a tricky and complicated business, and as such, governments should direct funding to reducing tax policies negatively impacting business."

- "Federal transfer payments to provinces that use incentive dollars to attract investment to another province should be terminated."

\section{Site selection factors - their importance}

\section{Corporate executive viewpoints}

Area Development Magazine has produced a respected annual survey and assessment of the importance of primary site selection factors and related change. The survey was instituted in 1986. The National Association of Manufacturers has been the distribution agent in recent years. Response rates average between five to eight percent of the total membership of the National Association of Manufacturers, but about 80 percent from firms with more than 500 employees.

Labour cost and the availability of skilled labour are dominant factors when considering the combined rating of very important and important. For the purpose of comparison, I have noted these factors in Figure 5 as they relate to the position of state and local incentives in the 19 annual surveys from 1986 to 2004 .

\footnotetext{
${ }^{5}$ Economic Developers Survey, March 2005.
} 
Figure 5: Importance of site selection factors, 1986 and 2004

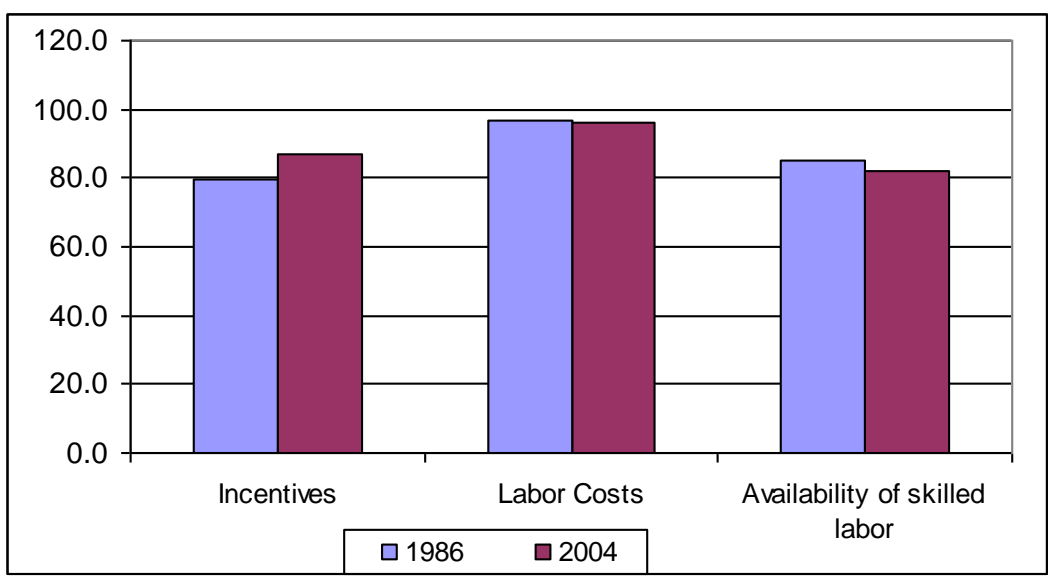

Source: Area Development site and facility planning survey, 1986 and 2004

Incentives have increased in importance during this period, from 79 percent to 87 percent (see Figure 6). This change is supported by other articles on the subject and the feedback from the electronic survey of Canadian economic developers. Labour cost remains strong at 96 percent, with the availability of skilled labour increasing in importance from 84 percent to 89 percent over the 1986 to 2004 period.

\section{Figure 6. Corporate executives survey}

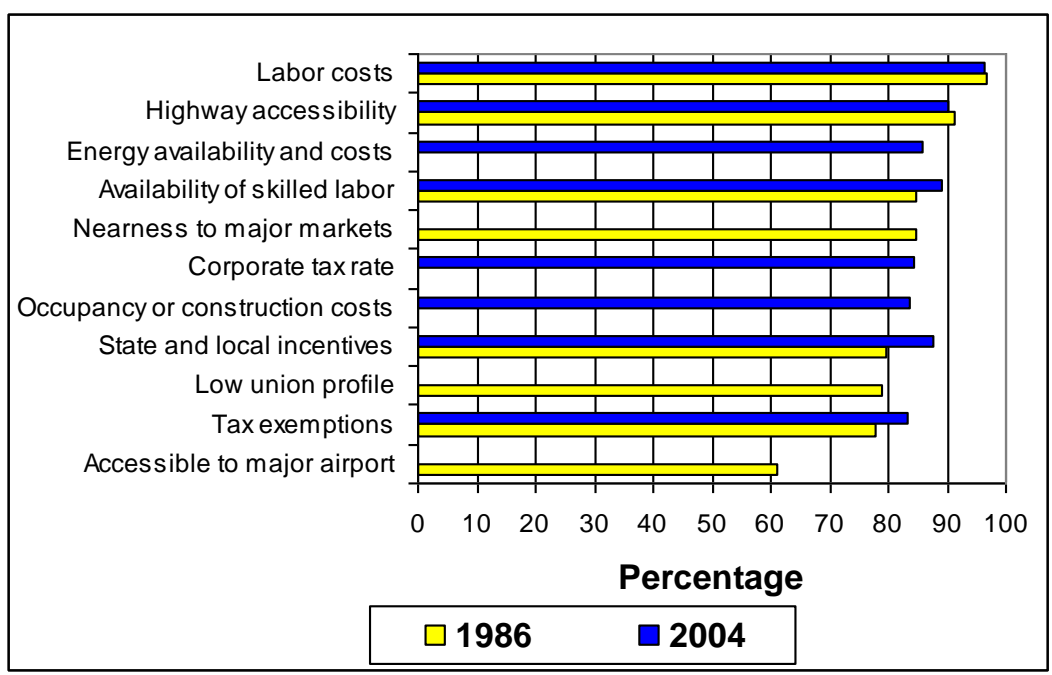

Source: Area Development site and facility planning survey, 1986 and 2004

Incentives and their importance to site selectors have increased significantly over the 19 years Area Development has conducted their survey. However, it lost some importance between the 2003 and 2004 surveys, declining five percent. 
Executives continue to recognize that incentives should not be the primary driver, that they will not go away, and that they cannot overcome a fundamental mismatch between a company's needs and the character of the community. ${ }^{6}$ Incentives can only marginally enhance an already sound choice of location.

The importance of incentives as the deal breaker is also the subject of debate between corporate executives and site location consultants. A trend is emerging that for large projects with major investment and job outputs, deal breakers can and do occur in the negotiations. As the North American workforce shifts to a service based economy, incentive programs targeting in the service sector tend to be more commonly offered. The jobs are higher wage positions than traditional manufacturing jobs.

\section{A consultant's perspective}

Consultants were surveyed for the first time by Area Development in 2004 in order to compare their perspectives with those corporate executives regarding site location factors. Labour cost ranked first in order of importance, similar to the response from corporate executives. Incentives however, were considered not as important, with a ranking of $6^{\text {th }}$ place to $4^{\text {th }}$ place by the executives. The growing importance of incentives was consistent with responses from corporate executives and economic developers (see Figure 7).

Figure 7. Consultant/service provider survey, combined ranking (very important, important)

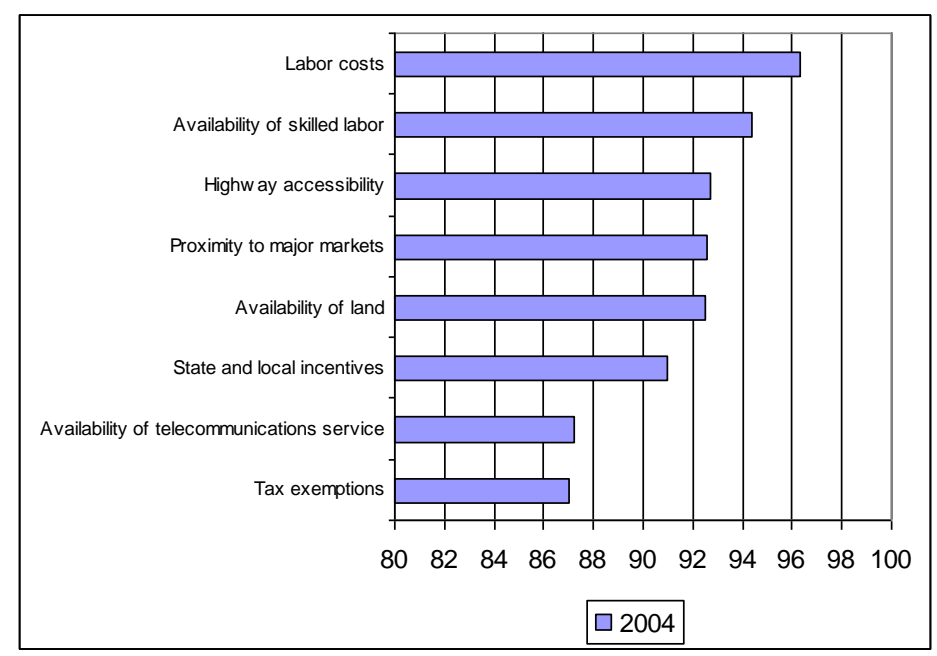

Source: Area development site and facility planning survey, 2004

${ }^{6}$ Area Development Survey, 2004. 


\section{Preferred incentives and their value}

The value of incentives and those most preferred in investment attraction is another area of debate but primarily between economic developers and corporate executives.

The findings from a survey completed by Stadtmauer, Balkin and Baggins were presented to the Cornet Global Summit in Salt Lake City in 2002. ${ }^{7}$ The survey included responses from 1400 industry related sources in the United States. To secure a broad perspective from those involved in the incentive marketplace, two separate surveys were created for corporate executives and another for economic developers.

The corporate executives want primary grants, sales tax abatements and subsidized land or building. The economic developers believe training assistance is more important. This is consistent with the responses to my personal interviews with Canadian and American economic development professionals.

The Area Development 2004 survey refined corporate executives priorities further with the inclusion of more specific reference to financial concessions as noted in Figure 8. Tax credits and tax exemptions top the list of important considerations.

Figure 8. Types of incentives considered most important when making a location decision

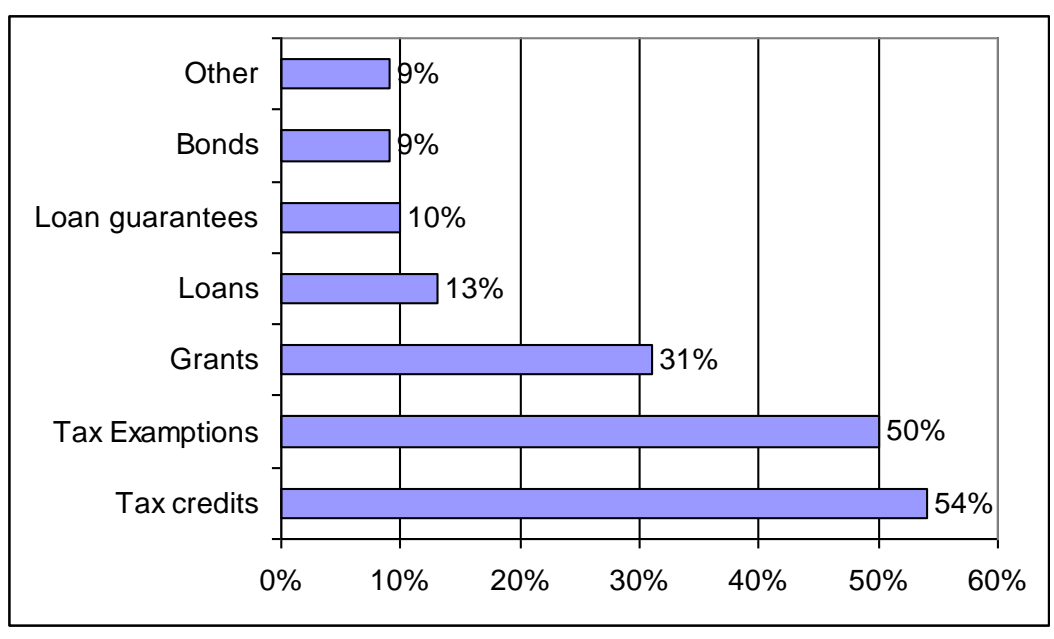

Source: Area development site and facility planning survey, 2004

Governments contend that each jurisdiction requires a toolbox of incentives to be flexible. ${ }^{8}$ Most states offer tax credits or abatements to attract new business, but each program is unique. Canadian provinces and the federal government focus more on tax credits and training or wage subsidies.

\footnotetext{
${ }^{7}$ Proceedings from Cornet Global Summit, Salt Lake City, Stadtamuer Bailkin Biggins, 2002.

${ }^{8}$ Peter Fisher, Enterprise Zone Incentives and the Spatial Mismatch Debate,

W.E. Upjohn Institute for Employment Research, Kalamazoo MI, January 2001.
} 
In terms of the incentive offering the highest value-added, low interest loans were touted by American economic developers as the most preferred option. A survey of 260 economic developers completed in Minneapolis in 2000 confirmed that low interest loans provide a revolving cycle of taxpayer dollars and allowed local businesses to leverage funds from financial institutions and public sector programs. Figures 9 and Figure 10 outline incentive offering preferences and indicate which incentive produces results in the most resources/dollars, and the greatest related value added.

\section{Figure 9. Which incentives do you offer?}

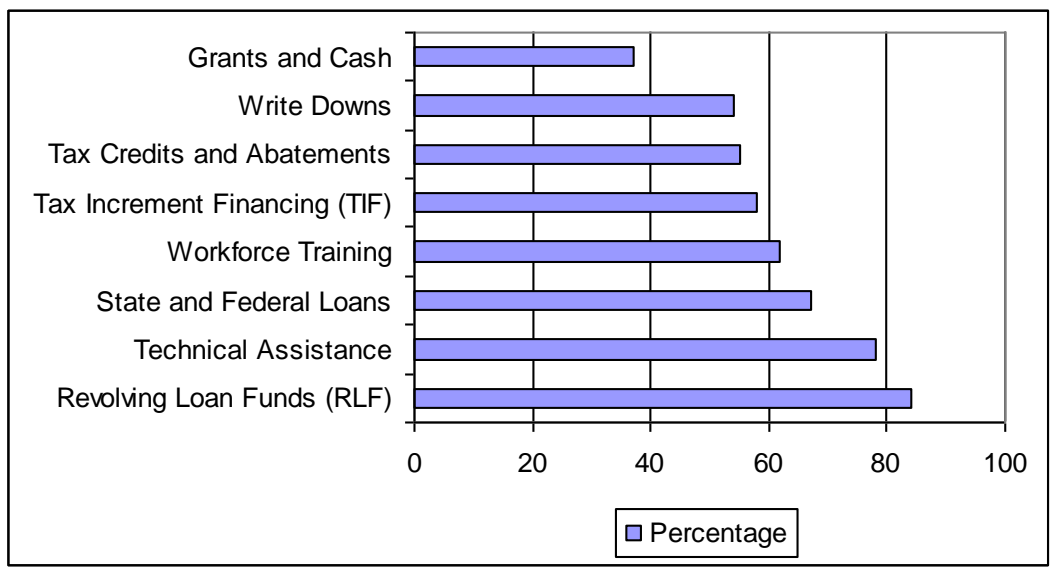

Source: Federal Reserve Branch of Minneapolis, R. Wirtz

Figure 10. Which incentive distributes the most resources/dollars, and which provides greatest value-added?

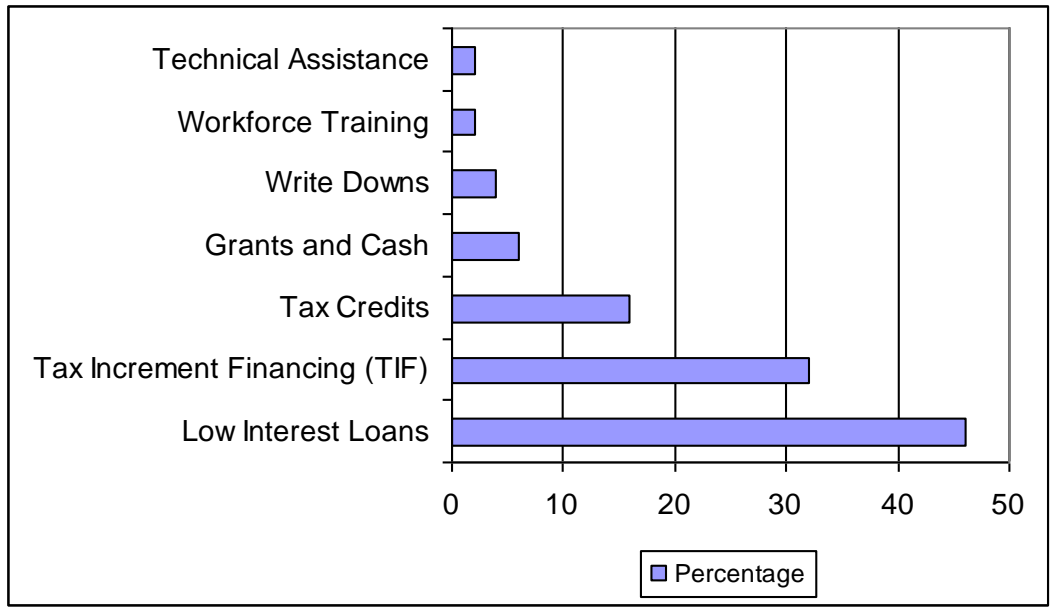

Source: Federal Reserve Branch of Minneapolis, R. Wirtz 
The true value of an incentive is closely aligned to the contribution of the new investment in that locality ${ }^{9}$. As such, the characteristics of the firm are important. Machinery-intensive firms respond more vigorously to property tax exemptions or abatements for machinery and equipment, firms with high margins and related profits may seek reductions in the rate of income taxation, energy-intensive firms will be attracted to exemptions of sale tax on fuel and electricity.

In Canada, where wage subsidies are offered by Human Resources and Skills Development Canada through a targeted wage subsidy initiative, this incentive can provide an offset when competing against American jurisdictions that tend to have more tools in their incentive attraction toolbox. For instance, wages are a much larger component of cost than taxes (about 14 times as large, on average), and wage rates can vary substantially between jurisdictions. If wage differentials of $\$ 1.00$ an hour or more are common when manufacturers compare sites, then an incentive package that provides the equivalent of a ten percent reduction is unlikely to exert a significant influence on the locations decision; tax differences will be swamped by wage differences. ${ }^{10}$

In Canada, where wage subsidies are offered by Human Resources and Skills Development Canada through a targeted wage subsidy initiative, this incentive can provide an offset when competing against American jurisdictions that tend to have more tools in their incentive attraction toolbox. For instance, wages are a much larger component of cost than taxes (about 14 times as large, on average), and wage rates can vary substantially between jurisdictions. If wage differentials of $\$ 1.00$ an hour or more are common when manufacturers compare sites, then an incentive package that provides the equivalent of a ten percent reduction is unlikely to exert a significant influence on the locations decision; tax differences will be swamped by wage differences. ${ }^{11}$

\section{Accountability and justification issues}

The balance between the benefits generated and the scale of the incentive offered and their ongoing cost is the true centre of debate on the incentive issue.

The revenue component to the community is represented by assessment and related property taxation, income and corporate taxation, employment, retail and housing sales and charitable contributions. These factors are improvements to the economy of the area.

The expense component includes the financial outlay of the incentive and contributions from all levels of government for infrastructure, health, education and protection.

\footnotetext{
${ }^{9}$ Ronald A. Wirtz, A Toolbox of Favors: A Kitty of Different Business Incentives Gives Communities Wherewithal to Close Deals, Fedgazette, July 2000.

${ }^{10}$ Graham Toft, Doing Battle over the Incentives War: Improve Accountability but Avoid Federal Noncompete Mandates, Indiana Economic Development Council Incorporated, May 1996.

${ }^{11}$ Graham Toft, Doing Battle over the Incentives War: Improve Accountability but Avoid Federal Noncompete Mandates, Indiana Economic Development Council Incorporated, May 1996.
} 
There are a number of related impacts, financial and non-financial, that can also be considered in the impact analysis, encompassing direct, indirect and induced factors. All contribute toward the ripple effect of the investment or retention of the existing investment and the related cost.

A review of papers and reports on accountability and justification of incentive identifies certain areas of misunderstanding or interpretation as to really what is driving the business decision. In the case of the American Enterprise Zones, there are different opinions between economic developers and economist on this point.

Enterprise zones are designated areas which target specific economic development policies. The number, size and mix of zone designated criteria are varied. The debate is whether the zone is socially or industrially driven based on the criteria and attitudes of policy makers. The direction is simply to impact on business decisions in a responsible manner to the state.

Enterprise zones have experienced growth and attracted firms and jobs. ${ }^{12}$ It was not the tax incentives offered that closed deals but was due more to the service/quality of life incentives. The tax breaks, particularly property tax abatement, were most useful in promoting growth, but on the average, taxes only represent two percent of a company's cost. More research is required to determine which incentives lead to growth.

The following statements are a summary of viewpoints expressed from both interviews with economic developers and from selected articles and related research on the subject:

\section{Incentive opponents}

- The incentive war is now on a large scale and over the long term will make the use of the incentive ineffective and unproductive. ${ }^{13}$

- Incentives are moving firms within the same region, resulting in no overall benefit to the broader economy.

- The existing businesses are paying part of the cost of the incentives through their taxes which are being provided to a handful of companies who may be competitors and ultimately putting the existing firms at a competitive disadvantage.

- Incentives are setting a dangerous precedent.

- From the broader perspective, incentives and their application is resulting in a zero-sum game at best.

- The eagerness of a company to accept incentives, with their required conditions for outputs, may damage the health of company over the medium term.

- Incentive deflects funding and consumes finite resources for public sector services such as roads, health care, education and public protection.

\footnotetext{
12 Frank D. Beck, Do State-Designated Enterprise Zones Work?, Illinois State University, Department of SociologyAnthropology, 1998.

${ }^{13}$ Arthur Rolnick, Winning Battles, Rather than the War, on EconomicDevelopment Subsidies, July 2000.
} 
- There is often an overstatement as to the social benefits of new jobs in areas of low unemployment where residents can already secure jobs.

- Economic professionals lack the required data on firms to properly assess the need for the incentive for a specific company.

- According to the Council of State Governments on Economic Development in the United States." Comprehensive reviews of past studies on the effects of incentives reveal no statistical evidence that business incentives actually create jobs". ${ }^{14}$

- The selection of firms to receive incentives is sometimes politically driven rather than based on the economic justification of the project itself.

- There is an overpay argument noted by critics on the incentives bidding war for high profile investments, particularly with attraction efforts for auto plants. For example, Pennsylvania spent 70 million dollars to convince Volkswagen to build a factory with a promise of 20,000 thousand jobs, yet the plant employed only 6,000 and shut down within a decade. ${ }^{15}$

\section{Incentive supporters}

- Incentives can generate enhanced benefits in areas where unemployment is high and thus providing new job opportunities for local residents and further value if the jobs being created are at higher wages than the norm for the community.

- Incentives that target off-shore investment provide a positive contribution to the national economy.

- Since business investment is more global and competition is tough, the incentive tool is essential.

- Trade agreements are often silent on the matter of incentives making cross-national competition more acceptable.

- The outlawing of incentives can place a burden on today's leaders who want to redress the errors of previous administrations by aggressively reinvesting. Incentives can enhance opportunities for this process.

- The zero-sum game argument on incentives is debatable as it is based on the premise that equal investments will have the same outputs in any economic setting. A cluster strategy enhances economic vitality and competitiveness. This would relate to different economic multipliers in different regions. Indirect and induced benefits would vary on the supplierbuyer relationships as would the demand for consumer goods. ${ }^{16}$

- Incentives demonstrate a pro-business attitude of the community which encourages companies to make long-term investments toward hopefully long term success.

\footnotetext{
${ }^{14}$ Gerald W. McEntee, The Problem with State Bidding Wars and Some Possible Remedies, American Federation of State, County and Municipal Employees, Washington, D.C., May 1996.

${ }^{15}$ Graham S. Toft, Doing Battle over the Incentive War: Improve Accountability but Avoid Federal Noncompete Mandates, Indiana Economic Development Council Incorporated, May 1996.

${ }^{16}$ Tim Bartik, Eight Issues for Policy toward Economic Development Incentives, W.E. Upjohn Institute for Employment Research, Kalamazoo MI, Spring 1995.
} 
- Tax revenues lost from tax competition is offset partially by increased taxes from other sources.

The arguments for or against incentives will continue, with the most passionate overtures focusing on the local accountability and justification factors and the real net gain or contribution to the local economy. As the Industrial Era gives way to the Information Age, economic wealth is being created by research, discovery and innovation, which is a pattern shifting companies' site selection focus to higher, rather than lower, cost areas.

This trend will change views regarding the role of incentives and the type of incentive offered. Regions with intellectual capital and support systems for innovation and research may not require incentives as primary tool for site selection.

Another trend gaining momentum is the improvement in accountability measures, with more disclosure requirements and tracking of the incentive and the justification of the investment over time. More scientific cost-benefit analysis is being advocated on by policymakers who are stressing more targeted approaches on the granting of incentives to high unemployment and depressed areas.

\section{Influencing factors}

The public responsibility issue in terms of granting incentives continues to be highlighted by various legislators and the media who note the mismanagement of funds for investment attraction and retention programs. The viewpoints extend from outright bans to more stringent accountability criteria for incentives.

There are two events in the United States that are receiving much interest due to their potential implications for the awarding of incentives. First, the Cono versus Daimler Chrysler case which is currently before the United States Six Court of Appeals. This will decide whether the practice of providing tax breaks and other subsidies to business is constitutional. The implication is that it may violate the Commerce Clause of the United States Constitution. In this example, the State of Ohio offered to Daimler Chrysler a 300 million dollar incentive package in exchange for maintaining long-standing jeep production in Toledo, instead of relocation to Michigan just over the border. The Commerce Clause was designed to prohibit state regulation and tax policy from interfering with economic activity between states.

This test case is receiving much attention by all sectors and jurisdictions due to impacts on the current 50 billion dollars of annual incentives provided to the private sector by United States jurisdictions. ${ }^{17}$

The second factor is the Sobanes-Oxley Act or SOX, which has global implications given its purpose to prevent financial malpractice and accounting scandals such as the Enron case. The

\footnotetext{
${ }^{17}$ Michael D. LaFaive, Are Targeted Incentives Constitutional? Mackinac Centre for Public Policy, 2004.
} 
Act came into effect in November 2004 and many firms are not in compliance with this legislation.

The most common area of contention relates to the creation of transparent and accountable systems for recording transactions, dealings and any kind of business correspondence. The implications suggest the firms need to be careful in what records and documents they delete. ${ }^{18}$

Policy makers suggest that this legislation will result in more effective communication of the incentive deal to the public including both the details of the offering and presumed related impacts/benefits.

\section{Conclusions}

The consensus from economic development professionals, consultants and corporate executives is that incentives have a role of importance in the site selection process. There is agreement even amongst opponents that the financial offerings are growing in importance despite some fluctuation in the rankings in the annual surveys on this subject. The required business fundamentals matching corporate needs to suitability of location are of primary significance.

The serious negotiations on the customized incentive package typically are near the end of the process, when qualified locations are identified. As such, incentives become more of a closing argument in firming up the all-important deal. This is not to say that incentive offerings are not part of the marketing message, but the details, scope and execution mechanisms are usually discussed at a later stage.

There are always some exceptions to the norm amongst the business sectors. For example, my own experiences on contact centre attraction confirm that this sector is one of the most aggressive in identifying incentive offerings in the initial stage of the site selection process. One large American firm in reviewing Eastern Ontario sites in 2002 demanded five years of free space in order for Brockville to qualify for preliminary consideration. Such demands generate distaste by economic developers for the use of incentives tool in site selection. This is compounded more when you factor the ability to pay argument which often is the key element by government policymakers touting the need for an even playing field between large urban and rural municipalities.

The real debate focuses on the accountability and justification factors associated with incentives. There are divisions between all parties as to their effectiveness and net economic outputs and impacts. The raiding of neighbouring jurisdictions and offering of incentives to move to the next county are often cited as examples. The use of federal contributions by one province going toward the incentive package for a firm in another province to attract business creates negative sentiments on the use of public funds.

${ }^{18}$ Will Sturgeon, Sarbanes-Oxley Compliance a Silicon.com Special Report, June 2004. 
There has been increased demand from firms seeking incentive concessions for the retention of their existing manufacturing operations, as well as the use of incentives by existing firms to compete for new product mandates to remain competitive. The debate of this issue is the precedent nature of this practice and the potential financial burden in meeting the demands for incentives to existing firms.

Another issue is the uneven playing field debate which is created when site selection focuses on the bidding between a large urban centre with strong financial resources and the smaller rural area which is unable to compete with the same generous incentives to the interested firm. Canada and the provinces are more willing to intervene with local government as opposed to their counterparts in the United States. Municipal restructuring and amalgamation can facilitate expansion opportunities for smaller rural communities who are part of the larger unit by the sharing of resources and the infusion of transfer payments for site location projects.

Some of the incentive requirements for a specific location may be tempered by the trend toward firms requiring intellectual capital for a specific type of knowledge based company, and as such, the firm may need to focus on high locations where this type of labour is situated. This may minimize the level of importance of other site location and operational cost for the need for this intellectual capital and lower the expectation for a major incentive package.

\section{Recommendations}

A number of recommendations are being considered in both Canada and the United States to address the many issues identified in the debate over utilization of public funds for investment attraction and retention. The suggestions involved better tools for project analysis and improved tracking, accountability and justification. The specific details are as follows:

- Better analytical tools to guide the incentive provider on the determination associated with the suitability and justification for incentives for specific firms and for specific locations.

- Broader policies on the eligibility for incentives targeting those areas and communities with the greatest need as demonstrated by factors such as high employment and under capacity.

- More aggressive clawback provisions on non-performance. Again the tools to accurately assess impacts and outputs are required.

- Less political interference in the negotiation process. The authority to implement the incentive program should be away from elected officials to an independent authority or commission.

- Clarity is required on the policy that defines the purpose for the incentive and to further differentiate between incentives that are a stimulus for economic potential, and incentives that are more of a reaction to economic distress. 
- Policy development should encompass a greater recognition of the social and quality of life factors associated with enriching economic development.

- Governments should consider the inclusion of a management system that identifies the proliferation pressures of incentives. This process would assist incentive providers to ensure a strategic direction on the program's purpose, the targeted geographic area or sector target and the anticipated economic impacts/benefits.

\section{Author Biography}

David Paul is the Director of Economic Development at the City of Brockville, Ontario.

\section{References}

Area Development Site and Facility Planning Magazine, Various Editions, Dennis J. Shea, Publisher, Westbury New York, 1986 to 2005

Bartik, Timothy J., Eight Issues for Policy toward Economic Development Incentives, W.E. Upjohn Institute for Employment Research, Kalamazoo MI, Spring 1995.

Beck, Frank D., Do State-Designated Enterprise Zones Work? Illinois State University, Department of Sociology-Anthropology, 1998.

Elmquist, Kara, Incentives and Industrial Location in Iredell County: A Community and Fiscal Impact Assessment, University of North Carolina at Charlotte, Department of Geography and Earth Sciences, January, 1999.

Engberg, John B., The Impact of State Urban Enterprise Zones on Business Outcomes, Carnegie Mellow University, H. John Heinz 111 School of Public Policy and Management, December 1998.

Farrell, Chris, The Economic War among the States, Business Week Commentator, Minnesota Public Radio, May, 1996.

Faulkner, Richard, Brockville A Social History 1890 to 1930, Waterway Press, Brockville, 1975.

Fisher, Peter, Enterprise Zone Incentives and the Spatial Mismatch Debate, Special Report/Viewpoint, W.E. Upjohn Institute for Employment Research, Kalamazoo MI, January 2001.

Helfinger, Michael, Enterprise Zones: Lessons from U.S. Experience, Ministry of Economic Development and Trade, Economic Development Strategy Branch, Draft Paper, September 2001.

KPMG, Competitive Alternatives, the CEO's Guide to International Business Costs, G-7 2004 Edition. 
Ladd, Helen F., Spatially Targeted Economic Strategies: Do They Work? Duke University, Cityscape, 1993.

LaFaive, Michael, Are Targeted Incentives Constitutional, Mackinac Centre for Public Policy, 2004.

McEntee, Gerald, W., The Problem with State Bidding Wars and Some Possible Remedies, American Federation of State, County and Municipal Employees, Washington, D.C., May 1996.

Rolnick, Arthur,J., Winning Battles, Rather Than the War, On Economic Development Subsidies, Fedgazette, Federal Reserve Bank of Minneapolis, July 2000.

Schriner, James A., Using Economic Development Incentives as a Marketing Tool, Economic \&Technology Development Journal of Canada, 1997.

Stadtmauer Bailkin Biggins, Economic Development Incentive Survey, PowerPoint Presentation at Cornet Global Summit, Salt Lake City, Spring 2002.

Sturgeon, Will, Sarbanes-Oxley Act-Compliance a Silicon.com Special Report, June 2004.

Survey Data from Economic Development Associations and Interviewing, March and April 2005.

Toft, Graham S., Doing Battle over the Incentives War: Improve Accountability but Avoid Federal Noncompete Mandates, Indiana Economic Development Council Incorporated, May 1996.

Wirtz, Ronald A., A Toolbox of Favors: A Kitty of Different Business Incentives Gives Communities Wherewithal to Close Deals, Fedgazette, July 2000. 


\title{
APPENDIX
}

\section{INCENTIVES AT A GLANCE}

\section{CANADIAN PROGRAMS}

This is a quick source of information on taxes and business incentives offered in Canada and the United States. This is not a comprehensive inventory but does demonstrate the diversity of assistance for both investment attraction and business development by jurisdiction.

\section{ALBERTA}

Basic Business Taxes

Corporate Income Tax: 11.75 percent and 33.87 percent when combined with base federal rate. Federal tax represents 21 percent basic tax plus 1.12 percent surcharge for all provinces. Represents weighted average of 12.5 percent tax rate which applies up to March 2004 and 11.5 percent thereafter.

Sales Tax: No sales tax. 7.0 percent federal goods and service tax.

Property Tax: 3.08 percent on land and buildings. Incorporates both property and property-based occupancy tax rates.

\author{
Business Incentives \\ Royalty Tax Reduction \\ Small Business Deduction \\ Foreign Investment Income Tax Credit \\ Business Tax Rebates \\ Western Economic Diversification (WED) \\ Alternative Sources of Financing Corporation (AFSC) \\ Duty referral Program \\ Agri-Processing Incentive Program \\ Canadian Adaptation Rural Development Fund \\ Research and Development Matching Investment Initiative \\ Industry Energy Research and Development Program \\ Industrial Cooperation Program \\ Commercial Building Incentive Program \\ Canadian Textile Program \\ Self Employment Program
}

\section{BRITISH COLUMBIA}

\section{Basic Business Taxes}

Corporate Income Tax: 13.50 percent and 35.62 percent when combined with base federal rate.

Sales Tax: 7.5 percent non refundable and 7.0 percent federal goods and service tax.

Property Tax: 2.56 percent on land and buildings.

\section{Business Incentives}

Film and Television Tax Credit and Production Service Tax Credit

Scientific Research and Experimental Development Tax Credit

British Columbia Mining and Exploration Tax Credit

Book Publishing Tax Credit

International Financial Activity Act (Tax Refunds) 
Venture Capital Programs

Employee Share Ownership Program

Labour Sponsored Funds Program

\section{MANITOBA}

\section{Basic Business Tax}

Corporate Income Tax: 15.00 percent and 37.12 percent when combined with base federal rate.

Sales Tax: 7.0 percent non-refundable. 7.0 percent federal goods and service tax.

Property Tax: 5.55 percent on land and buildings. Incorporates both property tax and property-based business/occupancy tax rates.

\section{Business Incentives}

Manufacturing Investment Tax Credit

Co-operative Education Tax Credit

Manitoba Research and Development Tax Credit

Community Enterprise Development Tax Credit

Manitoba Equity Tax Credit

Manitoba Film and Video Production Tax Credit

Mining and Exploration Tax Incentives

\section{NEWFOUNDLAND AND LABRADOR}

\section{Basic Business Tax}

Corporate Income Tax: 14.0 percent and 36.12 percent when combined with base federal rate.

Sales Tax: 8.0 percent refundable and 7.0 percent federal goods and services tax.

Property Tax: 3.80 percent on land and buildings. Incorporates both property tax and property-based business/occupancy tax rates.

\section{Business Incentives}

Manufacturing and Processing Profits Tax Credit

Small Business Tax Credit

Economic Diversification and Growth Enterprise Program (EDGE)

Direct Equity Tax Credit

Small Business Corporate Income Tax Holiday

Film and Video Tax Credit

Scientific Research and Experimental Development Tax Credit

Fisheries Loan Guarantee Program

Micro-Business Lending

Strategic Enterprise Development Fund

Canada/Newfoundland and Labrador Labour Market Development

Canada/Atlanta Provinces Cooperation Agreement on International Business Development

\section{NEW BRUNSWICK}

\section{Basic Business Tax}

Corporate Income Tax: 13.0 percent and 35.12 percent when combined with base federal rate

Sales Tax: 8.0 percent refundable and 7.0 percent federal goods and services tax. 
Property Tax: 4.71 percent on land and buildings.

\section{Business Incentives}

Strategic Assistance Program

Special Regional Funding Program

Atlantic Canada Opportunities Agency (ACOA)

New Brunswick Innovation Foundation

Research and Development Tax Credits

Provincial Sales Tax Rebate

Film Tax Credit Program

\section{NORTHWEST TERRITORIES}

\section{Basic Business Tax}

Corporate Income Tax: 14.0 percent and 36.12 when combined with base federal rate

Sales Tax: No sales tax.

Property Tax: Not available

\section{Business Incentives}

Risk Capital Investment Tax Credit

\section{ONTARIO}

\section{Basis Business Tax}

Corporate Income Tax: 14.0 percent and 36.14 percent when combined with base federal rate. A 2.0 percent manufacturing rebate is available which reduces the tax to 34.14 percent from the general corporate tax rate.

Sales Tax: 8.0 percent non refundable and a 7.0 percent federal goods and services tax.

Property Tax: 5.24 percent on land and buildings.

\section{Business Incentives}

Research and Development Challenge Fund

Ontario Innovation Tax Credit

Ontario Business-Research Institute Tax Credit

Ontario New Technology Tax Incentives

Ontario Graduate Transition Tax Credit

Ontario Corporate Minimum Tax

Opportunities Fund

Ontario Works

Job Connect

Apprenticeship Assistance

OSTAR

Research and Development Super Allowance

Ontario Innovation Trust

Ontario Research Performance Fund

Biotechnology Commercialization Centre Fund 


\title{
PRINCE EDWARD ISLAND
}

Basic Business Tax

Corporate Income Tax: 16.0 percent and 38.12 when combined with federal base rate. An 8.50 percent manufacturing tax reduction is available reducing corporate rate to 29.62 percent from general corporate tax rate.

Sales Tax: 10 percent non-refundable and 7.0 percent federal goods and services tax.

Property Tax: 3.81 percent on land and buildings.

\author{
Business Incentives \\ Business Support Program \\ Equity Investors Incentive Program \\ Rental Incentive Program \\ Enriched Investment Tax Credit \\ Share Purchase Tax Credit \\ Specialized Labour Tax Credit \\ Progressive Tax Rebate Program
}

\section{NOVA SCOTIA}

\section{Basic Business Tax}

Corporate Income Tax: 16.0 percent and 38.12 percent when combined with base federal rate.

Sales Tax: 8.0 percent refundable and 7.0 percent federal goods and services tax.

Property Tax: 5.59 percent on land and buildings. Incorporates both property tax and property-based business/occupancy rates.

\section{Business Incentives}

Community Economic Investment Fund

Small Business Rate Reductions

Recruitment and Training Assistance

Capital Cost Allowances

ISO 9000 and 14,000 Tax Credits

Special Rates for Manufacturing and Processing Profits

Research and Development Incentives and Tax Advantages

Investment Tax Credits

Atlanta Canada Opportunities Agency

Atlanta Innovation Fund

\section{QUEBEC}

\section{Basic Business Tax}

Corporate Income Tax: 8.9 percent and 31.02 percent when combined with federal base rate.

Sales Tax: 8.0 percent non-refundable and 7.0 percent federal goods and services tax.

Property Tax: 4.54 percent on land and buildings.

\author{
Business Incentives \\ Export Credit \\ Strategic Support for Investment Program (PASI) \\ Regional Economic Intervention Fund (FIER) \\ Interim Financing Tax Credit
}


Emploi-Quebec Employment Assistance

Assistance Program for Investment Project Start-up

Technology Partnership Canada

Refundable Tax Credit Precompetitive Research Projects

\section{SASKATCHEWAN}

\section{Basis Business Tax}

Corporate Income Tax: 17.0 percent and 39.12 percent when combined with base federal tax rate. A 7.0 percent manufacturing tax reduction is available or 32.12 rate after combined with base federal rate.

Sales Tax: 6.0 percent non- refundable and a 7.0 percent federal goods and services tax.

Property Tax: 4.33 percent on land and buildings.

\section{Business Incentives}

Co-operative Development Assistance Program

Co-operatives

Small Business Loans Assistance Association Program (SBLA Program)

Saskatchewan Financial Services Commission

Regional Economic Development Authorities

Employee Investment Program

\section{Figure 10. Corporate tax}

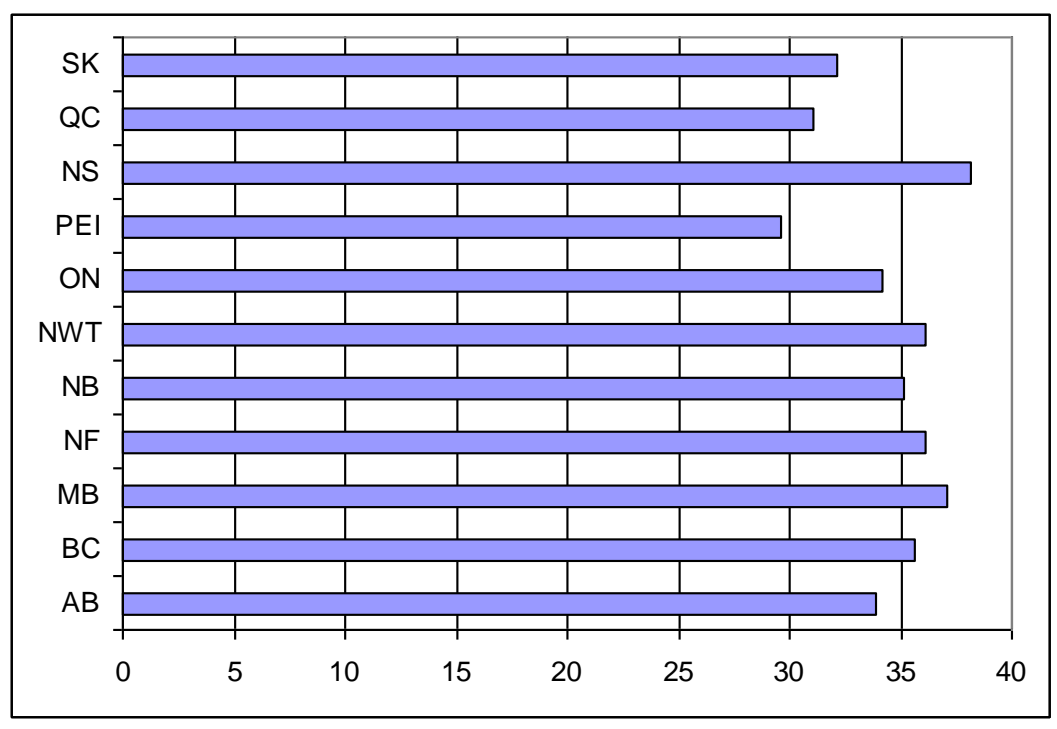

Source: KPMG competitive alternatives

Note: Ontario, PEI and Saskatchewan includes manufacturing tax reductions from general rate. 
Figure 11. Sales tax

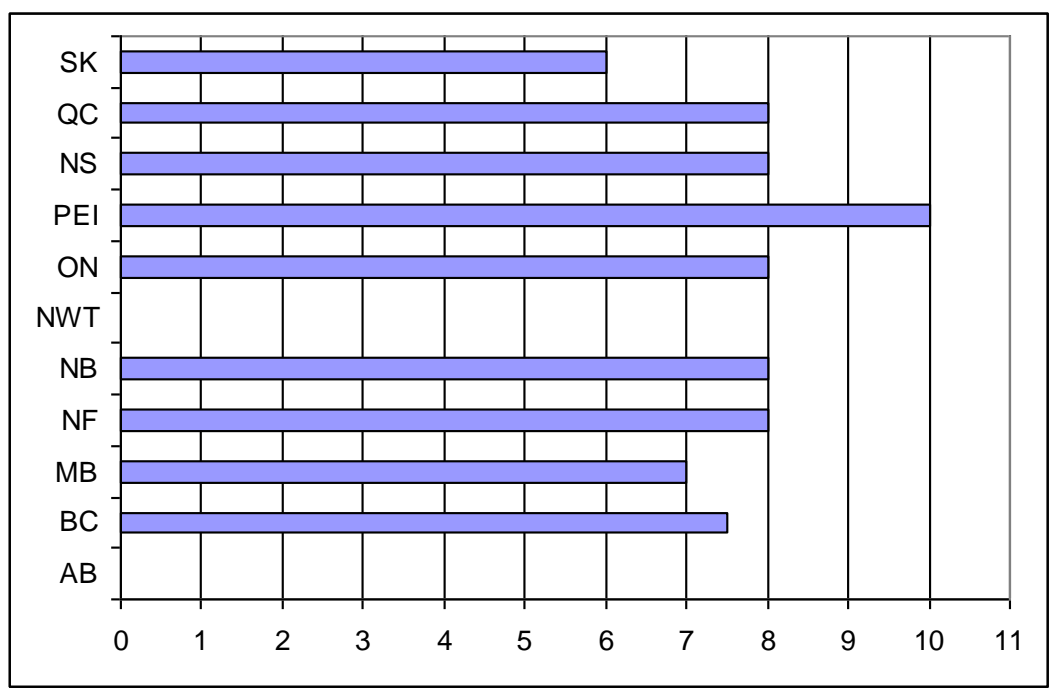

Source: KPMG competitive alternatives

Note: Newfoundland, New Brunswick and Nova Scotia have refundable sales tax.

Figure 12. Property tax

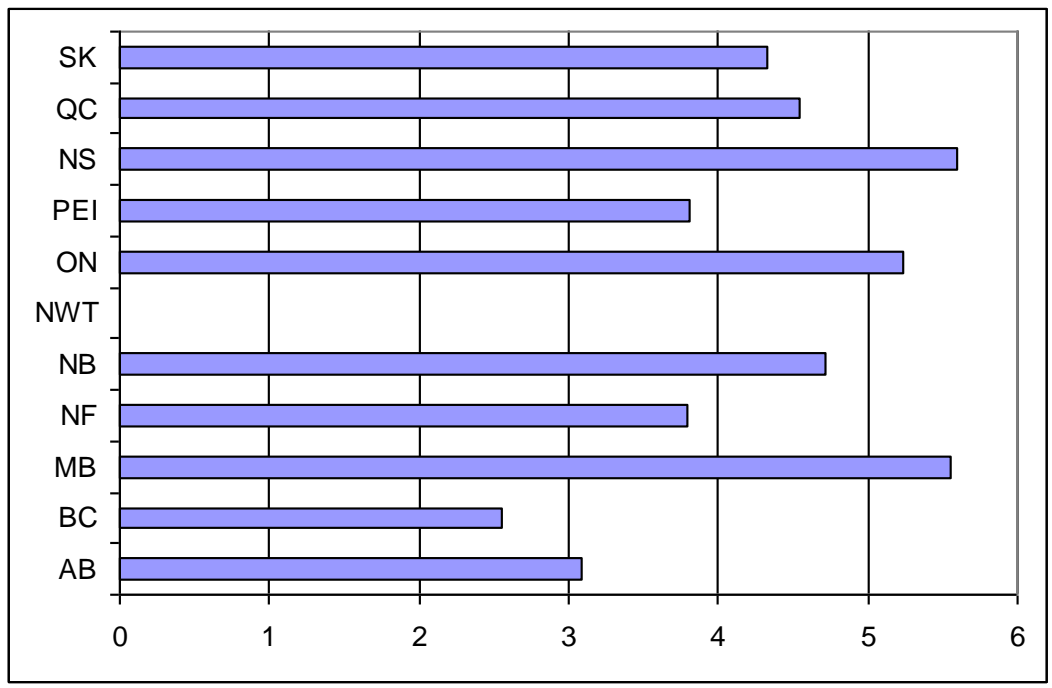

Source: KPMG competitive alternatives

\section{NATIONAL INCENTIVES FOR INVESTMENT IN CANADA}

Scientific Research and Experimental Development Program Industrial Research Assistance Program

Technology Partnership Canada

Business Development Bank Venture Capital Fund

Natural Science and Engineering Research Council of Canada

Precarn

Film Tax Credit Programs

Targeted Wage Subsidy Program 
Youth Internship

Self Employment Benefit Program

Summer Career Placement

Canada Community Investment Plan

\title{
United States Programs
}

\section{ALABAMA}

\section{Basic Business Taxes}

Corporate Income Tax: 6.5 percent of net income; deductions allowed for federal income tax paid or accrued.

Sales and Use Tax: 4 percent on gross proceeds of sales of tangible personal property and gross receipts of amusement businesses; 1.5 percent on manufacturing machinery and farm equipment; counties may impose additional tax.

Property Tax: The state tax is 6.5 mills. Additional tax may be levied by counties and municipalities. The assessment ratio for industrial property is 20 percent of fair market value.

\author{
Business Incentives \\ Income Tax Capital Credit \\ Sales and/or Use Tax Abatement \\ Property Tax Abatement \\ Inventory and Goods-in-Transit Exemptions \\ Pollution-Control Equipment Exemptions \\ Film Production Exemptions \\ Industrial Development Bonds \\ Economic Development Loan Program \\ Industrial Development (Site Preparation) \\ Grant Program \\ Industrial Access Bond Authority \\ Infrastructure Grant Program \\ Public Works and Facilities Grant \\ Appalachian Regional Commission Grants (37 counties) \\ Enterprise Zones/Favored Geographic Areas \\ Alabama Industrial Development Training \\ Delta Regional Authority (20 counties) \\ USDA Rural Development Loans
}

\section{ALASKA}

\section{Basic Business Taxes}

Corporate Income Tax: Corporations are taxed only on the portion of their net taxable income allocated and apportioned to the state. The state imposes no inventory tax, no gross receipts tax, no state sales tax, and no personal income tax.

Sales and Use Tax: Several boroughs and cities impose sales and use tax of up to seven percent on retail sales and certain locally provided personal services; neither Anchorage nor Fairbanks levies a retail sales tax. There are no state sales, income, gross receipts, or inventory taxes.

Property Tax: Real and personal property is taxed by boroughs and cities; the tax is levied primarily on real estate, but some communities also tax personal property. 


\section{Business Incentives}

Alaska Industrial Development and Export Authority (long-term financing) Foreign-Trade Zones

Alaska Growth Capital

Commercial Fishing \& Agriculture Bank (fishing, tourism, \& natural-resources loans)

Mining Exploration Tax Incentives

\section{ARIZONA}

\section{Basic Business Taxes}

Corporate Income Tax: Levied for all firms at 6.968 percent. The minimum filing amount is $\$ 50$.

Transaction Privilege and Use Tax: A transaction privilege tax of 5.6 percent is imposed on most business activities. A use tax of 5.6 percent is levied on use, consumption, or storage of certain tangible property.

Property Tax: Commercial and industrial property is assessed at 25 percent of full market value.

\section{Business Incentives}

\section{Enterprise Zones}

Empowerment Zones (Tucson) Foreign-Trade Zones

Industrial Development Bonds

Defense Restructuring

Military Reuse Zones

Healthy Forest Enterprise Program

Machinery and Equipment Tax Exemption

R\&D Tax Credits

Sales Tax Exemption for Manufacturing and Equipment

Tax Credits for Pollution-Control Equipment

Arizona Job Training Grants

\section{ARKANSAS}

\section{Basic Business Taxes}

Corporate Income Tax: Corporations and public utilities are taxed at a rate from 1 percent to 6.5 percent, as net taxable income increases.

Sales (gross receipts) and Use Tax: A 6 percent state sales tax is levied on the sale of tangible property, specific taxable services, and certain rental or lease payments.

Property Tax: The state imposes no property taxes; however, cities, counties, and special taxing districts do.

\section{Business Incentives}

Advantage Arkansas (income tax credit)

Tax Back (sales and use tax refund)

InvestArk Tax Credit (sales and use tax credit)

Create Rebate (payroll rebate)

ArkPlus (state income tax credit)

Targeted Businesses (transferable income tax credit; sales and use tax credit)

Research and Development (income tax credit)

"Super Project" General Obligation Bonds

Customized Training Incentives

Tuition Reimbursement Tax Credit

Recycling Equipment Tax Credit

Childcare Facility Tax Incentive

Arkansas Motion Picture Incentive 
Arkansas Tourism Development Act

Public Roads Improvement Credit

Freeport Law

Industrial Revenue Bonds

Arkansas Department of Economic Development Bond Guaranty Programs Arkansas Development Finance

Authority (bonds and bond guaranty program)

Community Development Block Grants

Small Business Development Loan

Arkansas Capital Corporation Group (loans, shared risks)

Arkansas Science and Technology Authority

Investment Fund (seed capital)

Venture Capital Investment Fund

Tax Increment Financing

\section{CALIFORNIA}

\section{Basic Business Taxes}

Corporate Income Tax: 8.84 percent (minimum tax is $\$ 800$ ).

Sales and Use Tax: 7.25 to 8.50 percent of receipts from sales or lease of taxable items, depending on county.

Property Tax: Assessed and collected locally by county governments; average tax rate is 1.1 percent of fair market value.

\section{Business Incentives}

California Employment Training Panel (ETP)

Industrial Development Revenue Bonds

R\&D Tax Credits (15 to 24 percent)

Designated Incentives:

- $\quad$ Enterprise Zones (39 statewide)

- Recycling Market Development Zones

- Foreign-Trade Zones

- Manufacturing Enhancement Areas

- Local Area Military Base Recovery Areas (LAMBRA5) California Office of Small Business:

- Loan Guarantee Programs

\section{COLORADO}

\section{Basic Business Taxes}

Corporate Income Tax: 4.63 percent on taxable income

Sales and Use Tax: 2.9 percent on goods purchased by a business that are not intended for resale and on all nonfood retail sales; local municipalities and counties may collect up to an additional 4.7 sales tax. Manufacturing equipment and other factors of production are exempt from state sales tax.

Property Tax: Assessed by local governmental units to fund public-school operations and local government services; industrial property is assessed at 29 percent of market value and mill levies vary; cities or counties in enterprise zones have the option of providing an incentive payment to new companies not to exceed difference in property taxes after development, less the property taxes prior to zone designation.

\section{Business Incentives}

Private Activity Bonds

Enterprise Zones 
Investment Tax Credits

Colorado First Customized Training Program

Colorado Existing Industry Training Program

Community Development Block Grant Funds

Regional Revolving Loan Program

\section{CONNECTICUT}

\section{Basic Business Taxes}

Corporate Income Tax: 7.5 percent of net income of corporations.

Sales Tax: 6 percent on sale and rental of most goods and certain services

Property Tax: Rates vary among local jurisdictions and are based on actual value of real and personal property; in practice, however, property is assessed at 70 percent of value.

\section{Business Incentives}

Connecticut Department of Economic and Community Development:

- Manufacturing Assistance Fund (loans, guarantees, tax credits)

- State Enterprise Zone Program

- Urban Jobs Program

- Industrial Parks Program

- Connecticut Technology Partnership

- Yankee Ingenuity Initiative

Connecticut Development Authority:

- Direct Loans

- Loan Guarantees (especially in urban areas)

- Low-Cost SBA 504 Loans

- Tax-Exempt Industrial Revenue Bonds

- Connecticut Job Training Finance Program (loans, assistance for job training)

\section{DELAWARE}

\section{Basic Business Taxes}

Corporate Income Tax: 8.7 percent on net income

License Fees and Gross Receipt Taxes: Minimal, but several business types including manufacturers are required to pay gross receipts tax; manufacturers pay a $\$ 75$ annual fee, plus 0.18 percent tax on gross receipts for all goods manufactured in Delaware; first $\$ 1$ million in monthly gross receipts not subject to taxation.

Property Taxes: Real estate is subject to county property taxes, school-district property taxes, and, if located in an incorporated area, municipal property taxes. The state does not levy a tax on real property. Effective property tax rates range from $\$ 0.002$ to $\$ 1.85$ per $\$ 100$ market value, depending upon location.

\section{Business Incentives}

Industrial Revenue Bonds

Prompt Bond Financing

Export-Import Financing

Delaware Strategic Fund

Delaware Innovation Fund

Customized Industrial Training

Competitiveness Fund

Technology-Based Small Business Seed Funds 
Clean Energy Grant

Venture Capital Fund

Brownfield Grants

Small Business Innovative Research Matching Grant Program

\section{FLORIDA}

\section{Basic Business Taxes}

Corporate Income Tax: 5.5 percent on apportioned income basis; $\$ 5,000$ exemption subtracted to compare net Florida taxable income; S-corporations (with exemptions) and partnerships generally pay no state corporate income tax on earnings.

Sales Tax: 6 percent; county option 0-2.5 percent. Current maximum state and county: 7.5 percent.

Property Tax: Locally fixed rates at fair market value on real and tangible personal property; no state levy on real and tangible property.

\section{Business Incentives}

Qualified Target Industry Tax Refund (QTI)

High-Impact Performance Incentive Grant (HIPD

Qualified Defense Contractor Tax Refund

Capital Investment Tax Credit (CITC)

Economic Development Transportation Fund (Road Fund)

Quick Response Training (QRT)

Incumbent Worker Training (IWT)

Aviation/Space Industries Sales Tax Exemptions

Rural \& Urban Job Tax Credit Programs

Expedited and Online Permitting

Enterprise Bond Program

Private Activity Bonds

Access to Venture Capital Network

Rural Community Development Revolving Credit Program

Semiconductor, Defense, or Space Sales and Use Tax Exemption (SDST)

Brownfield Redevelopment Bonus Refund

Florida Manufacturing Extension Program

Rural Infrastructure Fund

Sales and Use Tax Exemption on Machinery and Equipment

SBA 504 Subordinate Mortgage Loan Program

Florida Recycling Loan Program

Enterprise Zone Tax Incentives

\section{GEORGIA}

\section{Basic Business Taxes}

Corporate Income Tax: 6 percent of income apportioned to Georgia.

Sales Tax: 4 percent; some counties levy an additional I to 4 percent local sales tax.

Property Tax: Varied rates by county, currently ranging from 0.45 to 2.6 percent of fair market value; 1.2 percent average rate.

\section{Business Incentives}

Taxable and Tax-Exempt Industrial Development Bonds

Business Development Corporation of Georgia (loans) 
Advanced Technology Development Center

Business Loan Guarantee Program

Quick Start (job training)

Technical Colleges

Job Tax Credits and Investment Tax Credits

Inventory Tax Exemptions

Enterprise Zones

Loans for Rural Industry

Georgia Electronic Design Center (broadband communications)

Regional Revolving Loan Fund

Business and Industrial Loan Program

Foreign-Trade Zones

Export Finance Fund

R\&D Job Tax Credits

Headquarters Job Tax Credit

Entrepreneur \& Small Business Network

State of Georgia Tobacco Settlement Fund (One Georgia)

HOPE Scholarship Program (Helping Outstanding Pupils Educationally)

ICAPP (Intellectual Capital Partnership Program)

FaciliTech

\section{HAWAII}

\section{Basic Business Taxes}

Corporate Income Tax: 4.4 percent on first $\$ 25,000$ of taxable income; 5.4 percent on income up to $\$ 100,000 ; 6.4$ percent on amount exceeding $\$ 100,000$.

General Excise (Sales) and Use Tax: Rate ranges from 0.5 percent to 4 percent of the value of products, gross proceeds, or gross income according to type of business; 4 percent on retail sales of goods (except those exported) and services; 0.5 percent on manufacturing or wholesaling (except for exported goods)

Property Tax: Counties impose tax on all real property, buildings, and improvements to property. Property is assessed at 100 percent of fair market value, and taxes vary from 0.6 percent to I percent, depending upon type of property.

\section{Business Incentives}

Industrial Development Bonds

Customized Industrial Training

Hawaii Investment Attraction Program

Hawaii Strategic Development Corporation (venture capital)

Hawaii High Technology Development Corporation

Hawaii Small Business Innovation Research Grant

High Technology Business Tax Credit

Hawaii Internet Tax Freedom Act

Foreign-Trade Zones

Enterprise Zone Program

Business Action Center (permits and licenses)

Small Business Development Centers

\section{IDAHO}

\section{Basic Business Taxes}

Corporate Income Tax: 7.6 percent of taxable income 
Sales and Use Tax: 6 percent of retail sales price of taxable property; use tax of 6 percent on value of property, if not taxed at the point of sale.

Property Tax: Real and tangible personal property not exempted is subject to taxation and is assessed at market value. Tax rates vary among localities depending upon the aggregate levies imposed by cities, counties, and special taxing districts.

\section{Business Incentives}

Investment Tax Credit

Research \& Development Credit

Broadband Telecom Credit

New Jobs Credit

Net Operating Losses Credit

Tax Exemptions:

- Business Inventory

- Goods in Transit

- Pollution Control Equipment

- Industrial Machinery and Equipment

- Industrial Fuels and Raw Materials

- Property Tax Exemptions

Workforce Development Training Fund

Workforce Development Training Fund - Rural Component

Idaho Prime Loan Program

Industrial Revenue Bonds

Community Development Block Grant

Rural Community Block Grant

Tax Increment Financing

\section{ILLINOIS}

\section{Basic Business Taxes}

Corporate Income Tax: 4.8 percent on net income apportioned to Illinois, plus an additional 2.5 percent for corporate personal property replacement.

Sales Tax: State rate of 6.25 percent on retail purchases of tangible personal property plus optional additional local taxes ranging from $0.25-2.5$ percent in local jurisdictions.

Property Tax: Real property only is taxed and is assessed at 33.3 percent of fair market value. (Exception: Cook County property is assessed at 38 percent for commercial property and 36 percent for industrial property.)

\section{Business Incentives}

Participation Loan Program

Minority, Women, and Disability Participation Loan Program

Illinois Capital Access Program

Surety Bond Guaranty Program

Enterprise Zone Participation Loan Program Enterprise Zone Program (tax abatement)

High Impact Business Program

Tax Increment Financing Program

Community Development Assistance Program

Community Services Block Grant Loan Program

Recycling Grants Program

Illinois EDGE Tax Credits

Technology Innovation Grant Program

Business Development Public Infrastructure Program

Large Business Development Program 
Entrepreneurship Center Network

Employer Training Investment Program

Manufacturing Modernization Revolving Loan Program

Governor's Manufacturing Energy Efficiency Program

\title{
INDIANA
}

\section{Basic Business Taxes}

Inventory Tax: A statewide 100 percent deduction for the assessed value of inventory will be available to all Indiana taxpayers for assessments made in 2006 for taxes payable in 2007. As of January I, 2005, 38 counties have adopted the inventory deduction early, for taxes payable through 2006.

Corporate Income Tax: The business gross income tax was eliminated in 2003. The corporate adjusted gross income tax now allows corporations, with the exception of $\mathrm{S}$ corporations and not-for-profit organizations, a simplified calculation of income taxes. Indiana's 8.5 percent rate is one of most competitive tax rates in the nation.

Sales and Use Tax: 6 percent of sale price Property Tax: Real and personal property tax is assessed at I 00 percent of market value; property tax rates vary among local jurisdictions (exemptions).

\author{
Business Incentives \\ Industrial Development Grant Fund \\ Skills 2016 Training Grants \\ Economic Development for a Growing Economy (EDGE) Tax Credits \\ Energy Efficiency Grants and Incentives \\ Foreign-Trade Zones \\ Indiana Development Finance Authority Loan Guarantee Program \\ Certified Technology Parks \\ Hoosier Business Investment Tax Credit (HBI) \\ Venture Capital Tax Credit (VCI)
}

\section{IOWA}

\section{Basic Business Taxes}

Corporate Income Tax: Imposed on net income from sales within Iowa, after deducting 50 percent of federal corporate income tax; rates vary from 6 percent to 12 percent depending on income produced

Sales and Use Tax: A 5 percent sales tax is imposed on gross receipts from retail sales of tangible personal property, admissions, rentals, and certain services. Industrial machinery, equipment, and computers assessed as real property and used for manufacturing or to process data by insurance companies, financial institutions, or certain commercial enterprises are exempt from sales tax. Purchases of electricity or natural gas used directly in the manufacturing process are exempt from sales tax.

Property Tax: Levied by cities, counties, townships, and school districts. All properties are assessed at 100 percent of market value.

\section{Business Incentives}

Iowa New Jobs and Income Program (tax. credits and exemptions for large investments)

Enterprise Zones

Community Economic Betterment Account (loans, grants, guarantees, comprehensive management assistance)

Economic Development Set-Aside Program (loans, grants)

Iowa New Jobs Training Assistance

Targeted Small Business Financing (loans, grants)

Self-Employment Loan Program 
Urban Revitalization Areas

Tax Exemptions for Industrial Property

Tax Credits for New Employees and Research \& Development

RISE (Revitalize Iowa's Sound Economy) Funding

Entrepreneurial Ventures Assistance (EVA) Program (venture capital)

Public Facilities Set-Aside Program

\section{KANSAS}

\section{Basic Business Taxes}

Corporate Income Tax: 4 percent of net income plus a surtax of 3.35 percent on income in excess of $\$ 50,000$

Sales and Use Tax: 5.2 percent state rate on gross receipts from sales or leases of tangible personal property and certain services; cities and counties may add an additional maximum of I percent, with exemptions

Property Tax: Counties assess and administer the tangible property tax; each taxing district makes its own levy within the limits set by state legislature. Real and personal property is divided into classes and subclasses at different percentages of value, including 25 percent for real property used for commercial and industrial purposes, and for commercial and industrial machinery; 30 percent for gas and oil leases and royalties; 33 percent for public-utility property; other personal property varies, with exemptions. Credit on machinery and equipment based on taxes paid, with credit equal to 15 percent of property taxes for equipment used by a commercial or manufacturing enterprise.

\section{Business Incentives}

Economic Development Bonds (industrial revenue bonds)

Tax Increment Financing

Kansas Industrial Training and Retraining Programs

Enterprise Zones

High Performance Incentive Program

Job Expansion and Investment Tax Credits

IMPACT (Investments in Major Projects and Comprehensive Training)

Kansas Existing Industry Expansion Program (KEIEP)

Economic Development Block Grants

Kansas Economic Opportunity Initiative Fund (KEOIF)

Venture Capital Tax Credit

Research and Development Tax Credits

Incentives for Ethanol Production

\section{KENTUCKY}

\section{Basic Business Taxes}

Corporate Income Tax: Corporations are taxed on net taxable income apportioned to the state at rates from 4 percent to 8.25 percent, depending on income. Double weight is given to the sales factor in the property, payroll, and sales apportionment formula.

Corporation Franchise Tax: $\$ 2.10$ per $\$ 1,000$ of total capital employed in the business within the state

Sales and Use Tax: 6 percent of retail sales price of property sold and of cost price of property, including utilities, that is used, consumed, distributed, or stored; 6 percent of rental charged and cost of admissions; no local sales tax

Property Tax: Real property is taxed at a state rate of $\$ 0.131$ per $\$ 100$ and may also be taxed by local jurisdictions at varying rates; manufacturing machinery, telephone equipment, and pollution-control equipment are taxed only by the state at $\$ 0.15$ per $\$ 100$ assessed valuation. 
Business Incentives

Job Training Grants

Kentucky Economic Development Finance Authority (direct loans)

State Income Tax Credits:

- New and Expanded Manufacturing

- New Service and Technology Businesses

Bluegrass State Skills Corporation (training)

Industrial Development Bonds

\section{LOUISIANA}

\section{Basic Business Taxes}

Corporate Income Tax: Corporations deriving income from state sources are taxed from 4 percent (on first $\$ 25,000$ ) to 8 percent (more than $\$ 200,000$ ) on net income, depending upon amount of income.

Corporate Franchise Tax: $\$ 1.50$ per $\$ 1,000$ on first $\$ 300,000$ of capital employed in Louisiana; $\$ 3.00$ per $\$ 1,000$ above $\$ 300,000$

Sales and Use Tax: 4 percent levied on sale of tangible personal property at retail, as well as the use, consumption, distribution, or storage of tangible personal property and the sale of selected services in the state. There may be an additional local sales tax of up to 5 percent.

Property Tax: There is no state property tax. Land is assessed at 10 percent of fair market value. Business property is assessed at 15 percent of fair market value. Property tax rates are set by parishes and municipal governments and vary by parish.

\section{Business Incentives}

Quality Jobs Tax Rebate Program (5 percent or 6 percent of new gross payroll, based on wage levels)

Enterprise Zone Program (jobs tax credits and sales tax rebate)

Industrial Property Tax Exemption (10-year exemption)

Inventory Tax Credit (100 percent state income and franchise tax credit based on locally paid inventory taxes)

Jobs Tax Credit (credit based on new jobs created, location, and economically disadvantaged employees)

Employment Credit ( $\$ 750$ credit per eligible employee hired)

Louisiana Corporation Net Operating Loss Deduction

Federal Renewal Community Initiatives

Industrial Revenue Bonds

Volume Cap Tax Exemption for Small Manufacturers and Exempt Facilities Bonds

Community Development Block Grant (CDBG) funds (low-interest loans and infrastructure grants for companies

that hire low-and moderate-income people)

Direct, Guaranteed, and Participation Business Loans

Direct and Guaranteed Loans on Agricultural Products

Economic Development Awards Program (infrastructure grants and equipment loans)

Incumbent Worker Training Fund Program

Work Force Development and Training Fund

Louisiana Basic Skills Training Tax Credit

Research and Development Tax Credit (8 percent credit on qualified new research)

Biomedical Research and Development Park Incentives

Customized Computer Software

Development Sales Tax Exemption

Technology Commercialization Tax Credit

Biotechnology Sales and Use Tax Exclusion

Dedicated Research Investment Fund Tax Credit

Film \& Video Jobs Tax Credit

Film \& Video Investment Credit 
Film \& Video Sales and Use Tax Exemption

Other Credits and Exemptions:

- Tax credits for donations made to public schools

- Pollution-Control Devices and Systems Sales Tax Exclusion

- Tax credit for environmental equipment purchases

- Neighborhood assistance tax credit

- New markets credit

- Corporation tax credit; re-entrant jobs credit

- Rehabilitation of Historic Structures Tax Credit

\section{MAINE}

\section{Basic Business Taxes}

Corporate Tax: 3.5-8.93 percent levied based on income

Sales and Use Tax: 5 percent on sale of all tangible personal property

Property Tax: Real and personal property, unless exempt, is subject to taxation. Property is assessed according to just value, and rates vary with location.

\section{Business Incentives}

Finance Authority of Maine (FAME):

- Small Business and Commercial Loan Insurance (providing access to capital for Maine businesses)

- Economic Recovery Loan Program

- Export Finance Program

Department of Economic and Community Development:

- Pine Tree Development Zone Program

- Governor's Training Initiative

- Jobs and Investment Tax Credit

- Business Equipment Tax Reimbursement Program

- Research Expense Credit

- Super R\&D Credit

- High-Technology Investment Tax Credit

- Municipal Tax Increment Financing

- Employment Tax Increment Financing

- Employer Assisted Day Care Credit

- Clean Fuel Tax Credit

- Employer-Provided Long-Term Care Benefits Credit Maine Community Colleges:

- Maine Quality Centers (specialized technical training for workers in new or expanding business)

\section{MARYLAND}

\section{Basic Business Taxes}

Corporate Income Tax: 7 percent of net income

Sales and Use Tax: 5 percent on the sale or use of personal property within the state, including rental or leasing

Property Tax: Imposed by the state, counties, and municipalities on real property; varies by locality

\section{Business Incentives}

Industrial Development Financing:

- Loan Guarantees

- Taxable and Tax-Exempt Bonds 
- Trade Financing

Seafood and Aquaculture Loans

Energy Financing

Community Financing

Small Business Development Financing:

- Surety Bond Guaranty or Direct Bonding Daycare Financing

Investment Financing:

- Start-Ups

- First- and Second-Stage Technology-Driven Companies

Maryland Economic Development Authority and Assistance Fund

Smart-Growth Economic Development Infrastructure Fund

International Financing:

- Foreign-Trade Zones

Tax Incentives:

- Job Creation Tax Credits

- One Maryland Tax Credits

- Enterprise Zone Tax Credits

- Federal Empowerment Zones Incentives/Brownfields Revitalization Incentives

Employee Training

\title{
MASSACHUSETTS
}

\section{Basic Business Taxes}

Corporate Excise (Income) Tax: $\$ 2.60$ per $\$ 1,000$ of value of Massachusetts tangible property not taxed locally or net worth allocated to Massachusetts, plus 9.5 percent of net income; $\$ 456$ minimum excise. Single-sales factor apportionment formula for manufacturers, defense companies, and mutual fund corporations

Sales and Use Tax: 5 percent of gross receipts from retail sales or storage, use, or consumption of taxable property; local sales taxes are prohibited by law; sales and use tax exemption for $\mathrm{R} \& \mathrm{D}$ property

Property Tax: levied by individual localities at varying rates on the full and fair cash value of business and residential real estate; local property tax exemptions

\author{
Business Incentives \\ Capital Access Program \\ Emerging Technology Fund \\ Credits against Excise \\ Economic Development Incentive Program \\ Investment Tax Credits \\ Corporate R\&D Tax Credits \\ Tax-Exempt and Taxable Bond Financing \\ Brownfields Redevelopment Fund \\ Seafood Loan Program \\ Workforce Training Fund \\ R\&D Tax Credit
}

\section{MICHIGAN}

Single Business Tax (Corporate Tax): 1.9 percent of tax base, comprising value added during the production process. First $\$ 350,000$ of tax base is exempt. Note: Single Business Tax is being phased out at the rate of 0.1 percent per year and will be completely eliminated in 2010.

Sales and Use Tax: 6 percent; no local sales tax 
Property Tax: Assessed at 50 percent market value

\section{Business Incentives}

Job Creation Tax Credits (also includes high tech and brown fields)

Renaissance (Tax-Free) Zones

Smart Zones (business accelerators)

Technology and Productivity Consulting and Initiatives

Site Reclamation and Infrastructure

Improvements (grants, loans)

Brownfield Tax Incentives

Industrial and Personal Property Tax Abatement

Customized Job Training

Venture Capital and Equity Assistance

\section{MINNESOTA}

\section{Basic Business Taxes}

Corporate Income Tax: Corporations' rate is 9.8 percent of net taxable income in the state. Income is apportioned with sales weighted at 75 percent, and property and payroll weighted at 12.5 percent each.

Sales and Use Tax: The general sales and use tax rate is 6.5 percent. Special tooling and capital equipment and machinery used by manufacturers are exempt.

Property Tax: Personal property, including machinery and inventory, is exempt from property tax. Local governments tax all real property not specifically exempted. Most commercial and industrial property is assessed at 1.5 percent of the first $\$ 150,000$ of market value and 2.0 percent of the remainder. Varying tax rates are set by localities.

\section{Business Incentives}

Minnesota Investment Fund Program

Job Opportunity Building Zone (JOBZ) Program

Small Business Development Loan Program

Small Cities Development Program

Minnesota Job Skills Partnership

\section{MISSISSIPPI}

\section{Basic Business Taxes}

Corporate Income Tax: 3 percent on first $\$ 5,000$; 4 percent on next $\$ 5,000 ; 5$ percent for income over $\$ 10,000$

Corporate Franchise Tax: $\$ 2.50$ for each $\$ 1,000$ of capital invested in the state

General Retail Sales Tax: 7 percent

Property Tax: No state tax; local rates vary on real and tangible personal property with assessment ratio for most property at 15 percent of true value.

\section{Business Incentives}

Minority Business Enterprise Loan Program

Industrial Development Revenue Bond Program

Small Business Assistance Program

Advantage Jobs Act Program

Business Investment Act Program

Agribusiness Enterprise Loan Program

Energy Investment Program 
Mississippi Major Economic Impact Authority

Growth and Prosperity Act

\section{MISSOURI}

\section{Basic Business Taxes}

Corporate Income Tax: 5.2 percent net effective rate

Soles and Use Tax: 4.225 percent state rate; an additional 1.5 percent use tax for local jurisdictions; communities may adopt a local sales tax, generally ranging from 0.5 to 1 percent

Property Tax: Real property classified as commercial/industrial is assessed at 32 percent. All personal property is assessed at 33.3 percent of fair market value.

\section{Business Incentives}

Tax-Exempt Industrial Development Bonds

Missouri Development Finance Board

Industrial Infrastructure Grants

Brownfield Redevelopment Tax Credits

Enhanced Enterprise Zone Program

Missouri Customized Training Program

New Jobs Training Bonds

Rebuilding Communities Tax Credits

Venture Capital Resources

Local Property Tax Abatement

\section{MONTANA}

\section{Basic Business Taxes}

Corporate license (Income) Tax: 6.75 percent of all net income; corporations subject to apportionment may choose between worldwide combined reporting and the water's edge combination method of reporting; 7 percent rate for corporations choosing the water's edge option

Sales and Use Tax: None

Property Tax: Levied primarily by local jurisdictions, although the state, in ensuring that all property is treated fairly, handles property appraisal, assessment, and equalization of the value of all property for the purpose of taxation; tax liability is based on the market value of the property, the statutory tax rate for the appropriate class of property (20 property classes), and the mill levy in the jurisdiction where the property is located.

\section{Business Incentives}

Business Loan Participation Program (long-term, fixed-rate loans)

Direct State Loans

Industrial Training Program

Community Development Block Grant Program

Infrastructure Development Loans

Industrial Development Bonds

Aerospace and Technology Infrastructure Development Program 


\title{
NEBRASKA
}

\section{Basic Business Taxes}

Corporate Income Tax: 5.58 percent on the first $\$ 50,000$ and 7.81 percent on income of more than $\$ 50,000$; based on federal taxable income attributable to Nebraska operations

Corporate Unity Tax: To encourage investment in property and payroll, the formula considers sales only.

Sales Tax: 5.5 percent sales tax on gross receipts from retail sales, installation, maintenance, and rental of tangible personal property; certain utilities; admissions; producing, fabricating, processing, printing, or imprinting; lodging rentals for short periods; and certain enumerated services

Use Tax: Tax on storage, use, distribution, or consumption of tangible personal property and on any intangible property or services purchased at retail when the sales tax or retailer's use tax has not been paid

Property Tax: Levied by county and municipal subdivisions, including school districts; all property assessed at 100 percent of actual value; industrial sites located outside Nebraska cities normally taxed at a lower rate than property within city limits

\author{
Business Incentives \\ Industrial Development Revenue Bonds (low-interest financing) \\ Nebraska Investment Finance Authority \\ Economic Development Loan Program \\ Nebraska Development Finance Service (low-interest financing) \\ Local Development Corporations \\ Skill Training Employment Program \\ Nebraska Enterprise Opportunity Network \\ Community Improvement Financing \\ Nebraska Employment and Investment Growth Act (tax credits) \\ Nebraska Employment Expansion and Investment Incentive Act (tax credits) \\ Nebraska Redevelopment Act \\ Business Inventory Tax Exemption \\ Enterprise Zones \\ Invest Nebraska Act (tax credits)
}

\section{NEVADA}

Basic Business Taxes

Corporate Income Tax: None

State Business license: Each person, corporation, partnership, proprietorship, business association, and any other similar organization that conducts an activity for profit must obtain a state business license and pay an annual license fee of $\$ 100$. All nonprofit 501(c) organizations and government entities are exempt from the license requirements and the fee.

Payroll Tax: A payroll tax is levied in Nevada. For most businesses, except banks and specific financial activity businesses, the tax is 0.65 percent of total gross payroll. There is an allowable deduction for any health insurance costs incurred by the employer. Banks and financial institutions are taxed at a rate of 2 percent. The tax for each calendar quarter is due on the last day of the quarter and must be paid on or before the last day of the following month.

Sales and Use Tax: 6.5 percent on retail sales; localities may impose an additional 0.75 percent

Property Tax: Levied at 35 percent of the property's full cash value.

\section{Business Incentives}

Sales Tax Deferral and Abatement 
Property Tax Abatement

Freeport Law

Foreign-Trade Zones

Train Employees Now (TEN)

Personal Property Tax Abatement

Industrial Development Revenue Bonds

Renewable Energy Abatements

Recycling Property Tax Abatement

\section{NEW HAMPSHIRE}

\section{Basic Business Taxes}

Corporate Income Tax: 8.5 percent of net business profits allocable to the state; no personal income tax

Incorporation Fees: \$35 recording fee for articles of incorporation; fee for filing articles of incorporation is based on the authorized capital stock of the corporation; $\$ 50$ fee for addendum to articles of incorporation

Sales and Use Tax: None

Local Property Tax: Based on assessed valuation, and assessed, levied, and collected by municipalities; no property tax on inventory, machinery, or equipment

\section{Business Incentives}

New Hampshire Economic Development

Data System (computerized site-selection services)

Community Development Block Grants

New Hampshire Small Business Development Center

New Hampshire Business Finance Authority

New Hampshire Business Development Corporation

Export Financing

Industrial Development Bonds

Loan Guaranty Programs

Merchant Banc Venture-Loan Program

Industrial Research Center

Small Business Loans (venture capital funding)

\section{NEW JERSEY}

\section{Basic Business Taxes}

Corporate Income Tax: No capital stock, unincorporated business, business personal property, commercial rent or occupancy, or retail gross-receipts taxes

Corporate Business Tax: 9 percent of entire net income; for corporations with income under $\$ 100,000,7.5$ percent

Sales and Use Tax: 6 percent

Property Tax: Assessed and collected at the municipal level

\section{Business Incentives}

New Jersey Economic Development Authority:

- Business Employment Incentive Program (BEIP)

- Direct Loans/Loan Guarantees

- Statewide Loan Pool

- Tax-Exempt Bonds 
- Taxable Bonds

- Film Production Assistance

- Brownfield Redevelopment Loans

- Smart Growth Predevelopment Funding

- New Markets Tax Credits

Technology Centre of New Jersey

New Jersey Technology Funding Program

New Jersey Seed Capital Program

Technology Business Tax Certificate Transfer Program

Smart Growth Predevelopment Funding

New Jersey Commerce, Economic Growth \& Tourism Commission:

- Urban Enterprise Zone Program

- Sustainable Development Loan Fund

New Jersey Department of Labor:

- Workforce Development Program/Customized Training

- Springboard Fund II

Downtown Beautification Program

\section{NEW MEXICO}

\section{Basic Business Taxes}

Corporate Income Tax: A 4.8 percent tax rate applies to the first $\$ 500,000$ in net taxable income; $\$ 500,000-\$ 1$ million $=\$ 24,000$ plus 6.4 percent over $\$ 500,000$; more than $\$ 1$ million $=\$ 56,000$ plus 7.5 percent over $\$ 1$ million

Sales Tax (Gross Receipts Tax): 5 percent, but local-option add-on rates may bring the total over 7 percent. (The average is 5.75 percent.) Sales tax no longer applied to food

Compensating Tax: 5 percent

Property Tax: Real and tangible property is assessed at 33.3 percent of value, but many counties and municipalities offer abatements for new business locations and expansions.

\section{Business Incentives}

General Business Incentives:

- High Wage Jobs Tax Credit

- Rural Jobs Tax Credit

- Job Training Incentive Program

- Welfare-to-Work Credit

- Community Development Incentive Act (Property Tax Exemption)

- Child Care Credit

- Tax Exemptions Using Industrial Revenue Bonds

- Cultural Preservation Credit

- Border Residents' Credit

Industry-Specific Incentives:

- Agri-Business: Gross Receipts Tax Deduction

- Film Production

- Film: Gross Receipts Deduction

- 500 Fee-Free State Buildings Film Production Program

- Renewable Energy Production

- Double Weight Sales Factor

- Investment Tax Credit for Manufacturers

- Aerospace: Research \& Development

- Aerospace: Aircraft Manufacturing Tax Deduction

- Aerospace: Aircraft Refurbishing/Remodeling

- Aerospace: Spaceport Gross Receipts Tax 
- Technology: Research \& Development

- Technology: Rural Software Development

- Technology: Jobs Tax Credit

- Technology: Web Hosting

- Call Center: Gross Receipts Tax

- Tribal Land: Intergovernmental Business Credit

- Other: Distilling \& Brewing

\title{
NEW YORK
}

\section{Basic Business Taxes}

Corporate Income Tax: Principal tax is the greater of 7.5 percent of allocated net income; or 1.78 mills per dollar of investment capital allocated to New York; or 2.5 percent on the alternative minimum taxable base; or a minimum flat rate between $\$ 100$ and $\$ 10,000$, depending on gross payroll and gross assets. Tax on small business is 7.5 percent of entire net income if income is less than $\$ 290,000$.

Sales and Use Tax: The state rate is 4.25 percent of receipts from retail sales. (The rate will revert to 4 percent on June 1, 2005.) In New York City and the communities in the Metropolitan Commuter Transportation District, the tax is 4.5 percent. (The rate reverts to 4.25 percent on June 1, 2005.) Some counties and municipalities may impose additional sales and use taxes ranging from 1 to 4.375 percent, with exemptions.

Property Tax: Based on full value of real property including special franchises; equalization rate in each locality is determined by the State Office of Real Property Services. Personal property is not taxed.

\author{
Business Incentives \\ Direct Loans and/or Grants \\ Interest Rate Subsidies \\ Loans and Grants (working capital assistance) \\ Energy Cost Savings \\ Foreign-Trade Zones \\ Empire Zones \\ Infrastructure Assistance
}

\section{NORTH CAROLINA}

\section{Basic Business Taxes}

Corporate Income Tax: An income tax is levied at the rate of 6.9 percent on the portion of net income allocable to the state.

Sales and Use Tax: 4.5 percent on tangible personal items and other transactions, not including food; municipalities may add 2 to 3 percent for a combined sales tax rate of up to 7.5 percent; 1 percent on fossil fuels used in the manufacturing process; 1 percent on manufacturing machinery and parts, with a maximum tax on single machinery or equipment items at $\$ 80$ per article; 2 percent on natural gas

Property Tax: Local government levies on real and tangible personal property located within their jurisdictions; property assessed at 100 percent of appraised value; real property must be revalued every eight years.

\section{Business Incentives}

Industrial Revenue Bonds

Community Development Block Grants

Industrial Development Fund

Business Energy Loans

Customized New \& Expanding Industry Training

Foreign-Trade Zones 
Road and Rail Access Funds

Job Development Grant Program (enacted October 2002)

One N.C Fund

Investment Tax Credit

Job Creation Tax Credit

Central Administrative Office Tax Credit

R\&D Tax Credit

Worker Training Tax Credit

Development Zones

Pollution Abatement Equipment Tax Exemptions

N.C Ports Authority Import/Export Tax Credits

\section{NORTH DAKOTA}

\section{Basic Business Taxes}

Corporate Income Tax: Less than $\$ 3,000$ in N.D. income is taxed at 2.6 percent; $\$ 3,001$ to $\$ 8,000$ is taxed $\$ 78$ plus 4.1 percent of amount over $\$ 3,000 ; \$ 8,001$ to $\$ 20,000, \$ 283$ plus 5.6 percent of amount over $\$ 8,000 ; \$ 20,001$ to $\$ 30,000, \$ 955$ plus 6.4 percent of amount over $\$ 20,000$; amounts over $\$ 30,000$ are taxed $\$ 1,595$ plus 7 percent of amount over $\$ 30,000$. If a corporation elects to use the water's edge method to apportion its income, the corporation will be subject to an additional 3.5 percent surtax on its N.D. taxable income. (Note: The federal income tax is no longer allowed as a deduction in calculating N.D. taxable income.)

Sales Tax: 5 percent on retail sales of tangible personal property and certain services; 3 percent on farm equipment

Property Tax: Administered, levied (at different levels), collected, and expended at the local level to support schools, counties, cities, townships, and other local government units; state does not levy a property tax for general government operations; tax is 10 percent of assessed value for commercial property and 9 percent for residential property.

\section{Business Incentives}

Department of Commerce:

- North Dakota Development Fund (gap financing)

- Bank of North Dakota:

- PACE (interest buy-down program)

- MATCH (low-interest loans)

- Business Development Loans

- Job Service North Dakota:

- Workforce 2000

- North Dakota New Jobs Training Program

\section{OHIO}

\section{Basic Business Taxes}

Corporate Franchise Tax: 4.00 mills on net worth with $\$ 150,000$ maximum liability, or 5.1 percent on the first $\$ 50,000$ of net income plus 8.5 percent on net income in excess of $\$ 50,000$, or minimum tax of $\$ 50$

Corporate Organization and Qualification Fees: Initial license fee of $\$ 85$ for companies based outside Ohio; $\$ 0.10$ per share for the first 1,000 shares of authorized capital stock to $\$ 0.0025$ per share in excess of 500,000 for Ohiobased companies

Sales and Use Tax: 5 percent on retail sales and rental of tangible personal property, on repair or installation of such property, and on sale of selected services; counties and transit authorities can impose sales and use taxes up to 1.5 percent. 
Property Tax: Assessed by cities, counties, and special tax districts on 35 percent of true value for real property and 25 percent of true value for personal property

\author{
Business Incentives \\ Economic Development Financing \\ SBA 504 Loan Program \\ Small Business Innovation Research Program \\ Community Development Block Grants \\ Revolving Loan Funds \\ Enterprise Zones \\ Minority Business Development Financing \\ Ohio Investment Training Program \\ Enterprise Bond Program \\ Job Creation Tax Credit \\ Machinery Investment Tax Credit \\ Community Reinvestment Areas \\ Tax Increment Financing \\ Business Development Grants
}

\title{
OKLAHOMA
}

\section{Basic Business Taxes}

Corporate Income Tax: 6 percent of federal taxable income earned in Oklahoma

Sales and Use Tax: 4.5 percent state rate; most cities levy an additional tax of 1 to 4.25 percent; counties may levy an additional tax up to 2 percent.

Property Tax: Levied on both real and tangible personal property at the county level

\section{Business Incentives}

Oklahoma Quality Jobs Program ("cash back" incentive for major manufacturing and service employers with rebates up to 5 percent of taxable wages for up to 10 years)

Oklahoma Small Employer Quality Jobs Program ("cash-back" incentive payments for firms with 90 employees or fewer)

American Indian Land Usage (accelerated depreciation for federal tax purposes and state tax savings)

Industrial Development Bonds

Customized Training for Industry

Job Creation Tax Credit

Five-Year Property Tax Abatement

Oklahoma Finance Authorities:

- Pooled Business Finance Program

- Tax-Exempt Manufacturing Industrial Development Bond Program

Bid Assistance Centers (assistance in securing federal government contracts)

Oklahoma Center for Science and Technology (tech-transfer programs) Freeport Law

Construction Materials Sales Tax Refunds Aircraft Maintenance or Manufacturing Facility Sales Tax Refunds

Venture Capital Tax Credit

New Markets Tax Credit

\section{OREGON}

\section{Basic Business Taxes}

Corporate Excise Tax: 6.6 percent on net Oregon income of corporations doing business in the state 
Sales and Use Tax: None

Property Tax: Privately owned real estate and personal property used to produce income are subject to tax by local taxing districts such as schools, cities, and counties. Statewide property tax limitation of 1.5 percent of real market value

\author{
Business Incentives \\ Enterprise Zones \\ E-Commerce Enterprise Zones \\ Small City Business Tax Exemption \\ Commercial Properties under Construction \\ Property Tax Exemption \\ Business Energy Tax Credit \\ Pollution-Control Tax Credit \\ Research Tax Credit \\ Strategic Investment Programs for Capital Intensive Industries \\ Job Training Program \\ Industrial Development Bond Program \\ Oregon Business Development Fund \\ Small-Scale Energy Loan Program \\ Oregon Port Revolving Loan Fund \\ Oregon Capital Access Program \\ Oregon Credit Enhancement Fund
}

\title{
PENNSYLVANIA
}

\section{Basic Business Taxes}

Corporate Net Income Tax: 9.99 percent of taxable income based on federal returns, with certain additions and deductions allocated to Pennsylvania (Note: The Commonwealth has decoupled from the federal Job Creation and Worker Assistance Act of 2002)

Capital Stock and Foreign Franchise Tax: 6.99 mills for tax year beginning 2004, and a one-mill reduction per year thereafter through 2010, after which the tax is eliminated

Sales and Use Tax: 6 percent of purchase price of tangible personal property and certain services, with exemptions. A local sales tax of 1 percent is collected on the sale of taxable goods and services initiated from a location in Philadelphia and Allegheny counties.

Property Tax: Based on fair market value of property; rates vary among local jurisdictions; no state tax

\author{
Business Incentives \\ Building PA \\ Business in Our Sites Grants and Loans \\ Core Industries (expanded machinery and equipment loan program) \\ Community Economic Development Loan Program (CEO) \\ Customized Job Training Program (CJT) \\ Educational Improvement Tax Credit Program (EITC) \\ Export Finance Program (EFP) \\ New Communities/Enterprise Zone Program \\ First Industries Fund \\ Infrastructure Development Program (IDP) \\ Infrastructure and Facilities Improvement Program \\ Industrial Sites Reuse Program (ISRP) \\ Job Creation Tax Credits (JCTC) \\ Keystone Innovation Zone (KIZ) \\ Keystone Opportunity Zones (KOZ)
}


Machinery and Equipment Loan Fund (MELF)

Neighborhood Assistance Program (NAP) Tax Credits

Neighborhood Assistance Program Comprehensive Service Program NAP/CSP)

Neighborhood Assistance Program Enterprise Zone Tax Credit Program (NAP/EZP)

New PA Venture Capital Investment Program

New PA Venture Guarantee Program

Opportunity Grant Program (OGP)

PA Economic Development Financing Authority (PEDFA) Bond Programs

PA Capital Access Program (PennCAP)

PA Industrial Development Authority (PIDA)

P A Infrastructure Investment Authority (Penn VEST)

PA Minority Business Development Authority (PMBDA)

PA Pollution Prevention Assistance Program

Rail Freight Assistance (RFA)

Research and Development Tax Credit

Second Stage Loan Program

Small Business First (SBF)

Technology Investment Programs

Venture Capital

Tax Increment Financing (TIF) Guarantee Program

Underground Storage Tank Upgrade Loan Program (USTULP)

Work Force Investment Act of 1998 (Title I)

Guaranteed Free Training Program (GFT-WEDnetPA)

Workforce Leadership Grants

Industrial Resource Center Network (IRC)

Small Business Development Centers (SBDCs)

Pennsylvania Technical Assistance Program (PennTAP)

\section{PUERTO RICO}

BASIC Business Taxes_(For Qualified Industries)

Corporate Income Tax: Domestic Puerto Rico corporate tax rates range from a maximum 7 percent rate to a minimum zero percent rate for pioneer projects. Corporations are exempt from U.S. federal taxes on active business profits earned in Puerto Rico as long as these profits are invested outside the mainland.

Property Tax: Under 1 percent

\section{Business Incentives}

Special Fund for Economic Development

R\&D Incentives Program

Government Development Bank (long-term and large loans)

AFICA (tax-exempt IDBs)

Puerto Rico Economic Development Bank (loans and loan guarantees)

PRIDCO:

- Fast-Track Permitting Assistance

- Technical \& Other Assistance

Machinery and Equipment Tax Exemptions

Municipal License Tax Exemptions

Property Tax Exemptions

Job Training Costs Deduction (200 percent)

Training Grants and Incentives 


\section{RHODE ISLAND}

\section{Basic Business Taxes}

Corporate Income Tax: 3-9 percent of net income, subject to the Jobs Development Tax Rate Reduction

Sales and Use Tax: 7 percent

Municipal Property Tax: Rates vary; no county taxes

Business Incentives

Corporate Income Tax Rate Reductions for Job Creation

Investment Tax Credits

R\&D Tax Credits

Job Training Tax Credit \& Grants

Employer's Apprenticeship Tax Credit

Educational Assistance and Development Credit

Adult Education Tax Credit

Enterprise Zones

Historic Preservation Investment Tax Credit

Small Business Capital Investment Tax Incentives

Telecommunications Sales Tax Exemption

Bonus Program Private Participation Tax Credit

Child and Adult Day Care Tax Credit

Industrial Revenue Bonds

Tax-Exempt Small Issue Bonds

Small Business Loan Fund Program:

- Smart Building Initiative

- Rhode Island Urban Enterprise Equity Fund

- Brownfields Cleanup Revolving Loan Fund

\section{SOUTH CAROLINA}

\section{Basic Business Taxes}

Corporate Income Tax: 5 percent of taxable income derived from South Carolina operations, with exemptions

Sales and Use Tax: 5 percent on gross receipts from retail sales or leases of tangible personal property; a local option sales tax of an additional 1 percent or 2 percent in some counties

Property Tax: No state tax on real or personal property; assessed value and millage rates set locally except for manufacturing, distribution, corporate headquarters, and corporate office facilities, which are handled by the state's tax commission

\section{Business Incentives}

Jobs Economic Development Authority:

- Loans

- Taxable Industrial Development Bonds

- Tax-Exempt Industrial Development Bonds

Carolina Capital Investment Corporation (loans)

Export Working Capital Guarantee Program

Business Development Corporation of South Carolina (loans)

Tax Increment Financing for Redevelopment Areas

Foreign-Trade Zones

Supplemental Economic Development Funds

Job Development Credit 


\section{SOUTH DAKOTA}

\section{Basic Business Taxes}

Corporate Income Tax: None

Retail Occupational Sales and Use Tax: 4 percent on retail sales of tangible personal property and certain services, except 3 percent on farm machinery and 3 percent on oil and gas field services

Property Tax: Property tax is imposed on all real property. However, personal property, including business inventories and machinery and equipment, is exempt. Properties are assessed where located.

\section{Business Incentives}

REDI Fund (low-interest loans)

S.D. Economic Development Finance Authority (pooled bond program) Industrial Revenue Bonds

MicroLoan South Dakota (small business loans)

Workforce Development Training

Agricultural Processing and Export (APEX) Loan Program

Value-Added Agriculture Subfund (feasibility and marketing studies)

\section{TENNESSEE}

\section{Basic Business Taxes}

Corporate Excise Tax: 6.S percent on net earnings

Franchise Tax: $\$ 0.25$ per $\$ 100$ based on the taxpayer's net worth

Sales and Use Tax: 7 percent state and I percent to 2.75 percent local

Property Tax: Local only; counties levy property tax on real and personal property

\section{Business Incentives}

Fast Track Infrastructure Development Program (FIDP)

Community Development Block Grants

Private Activity Bonds

Revolving Loan Funds

Tennessee Valley Authority (revolving loans)

Tennessee Child-Care Facilities Program

Rural Economic \& Community Development (loan and grant programs) Small Business Administration:

- 504 loans

- 7A loans

- Microloans Demonstration Program

Small Business Energy Loan Program

Industrial Highway Access ARC (grants)

Corporate Headquarters Tax Credit

Job Skills Program

Fast Track Job Training Assistance Program

\section{TEXAS}

\section{Basic Business Taxes}

Corporate Franchise Tax: Imposed on all corporations that do business in the state or that are chartered or authorized to do business in the state, measured by net taxable capital and by net taxable earned surplus apportioned to the state; apportionment is by a single gross receipts formula; the tax rate on capital assets is 0.25 percent or $\$ 2.50$ per 
$\$ 1,000$ of net taxable capital; the tax rate on net earned surplus is 4.5 percent; corporations calculate the franchise taxes due on taxable capital assets and on taxable earned surplus, paying the greater of the two amounts; there is no minimum tax and no taxes are due on liabilities of less than $\$ 100$.

Sales and Use Tax: 6.25 percent on retail sales of tangible personal property and certain labor and services; cities, counties, and transit authorities may add to the sales tax up to a maximum combined state and local rate of 8.25 percent, with exemptions.

Property (Ad Valorem) Tax: No state property tax; real and tangible personal property is taxed at varying rates by local government and special taxing districts; local taxing entities have the option to exempt freeport goods.

\author{
Business Incentives \\ Texas Enterprise Fund \\ Industrial Revenue Bonds \\ Rapid Response Program (re-employrnent assistance) \\ Texas Capital Fund: \\ - Real Estate Development Program \\ - Infrastructure Development Program \\ - Main Street Program \\ Texas Enterprise Zone Program \\ Defense Economic Readjustment Zone Program \\ Foreign Trade Zones \\ Maquiladoras \\ Texas Leverage Fund \\ Skills Development Fund \\ Linked Deposit Program \\ Texas Capital Access Fund \\ Texas Agricultural Finance Authority Financial Assistance Programs (agricultural): \\ - Loan Guaranty Program \\ - Direct Loan Program \\ - Loan Participation Program \\ Linked Deposit Program (agricultural) \\ Young Farmer Loan Guaranty Program (agricultural) \\ Farm and Ranch Finance Program (agricultural) \\ Research \& Development Credit \\ Jobs Creation Credit \\ Capital Investment Credit \\ Rural Development Finance Program (agricultural)
}

\title{
UTAH
}

\section{Basic Business Taxes}

Corporate Income and Franchise Tax: 5 percent on taxable income

Sales and Use Tax: The maximum state sales tax is 6.35 percent.

Property Tax: Based on assessed property valuation; assessment levels are uniform throughout the state, but tax rates vary from city to city

\author{
Business Incentives \\ Industrial Development Bonds \\ Tax Increment Financing \\ Custom Fit Training Program \\ Research \& Development (R\&D) Tax Credits \\ Enterprise Zones
}


Industrial Assistance Funds

Manufacturing Equipment Sales Tax Exemption.

Short Term Intensive Training (STIT)

Workforce Investment Act (WIA)

Recycling Market Development Zone Program

Revolving Loan Funds

Aerospace/Aviation Development Zones

Aerospace/Aviation Tax Increment Finance (AATIF)

\section{VERMONT}

Basic Business Taxes

Corporate Income Tax: 7.0 percent on net income up to $\$ 10,000 ; \$ 700$ plus 8.1 percent on $\$ 10,001$ to $\$ 25,000$; $\$ 1,915$ plus 9.2 percent on $\$ 20,001$ to $\$ 250,000$; $\$ 22,615$ plus 9.75 percent on $\$ 250,00$ I and over; minimum tax of $\$ 250$

Corporate Organization and Qualification Fees: Domestic - \$75; foreign \$100 flat entrance fee

Sales Tax: 6 percent of taxable sales, purchases, charges, and rentals; use tax applies to storage, consumption, or use of tangible personal property or services, unless already subject to sales tax; meals and rooms taxed at 9 percent

Property Tax: The base education tax rate for homestead property is $\$ 1.05$. The base tax rate for nonresidential property is $\$ 1.54$. A statewide education tax is imposed on these two classes of property at different rates (2 V.SA Chapter 135). The basis for this classification is the Homestead Declaration. Any property that is not a homestead is nonresidential property. The homestead education tax rate in each municipality depends upon the $1<1$ cal per pupil spending. Both the homestead and nonresidential education tax rates are adjusted by the local common level of appraisal. Each town will receive notice on or about June 30 of the education rates to be levied.

\section{Business Incentives}

Industrial Development Bonds

Vermont Training Program

Vermont Economic Progress Council (VEPC) Tax Credits:

- Economic Advancement Tax Incentives

- Downtown Development Incentives

Financial Services Incentives

High-Tech Tax Incentives

R\&D Tax Credit

Property Tax Exemptions

Machinery and Equipment Sales Tax Exemption

\section{VIRGINIA}

\section{Basic Business Taxes}

Corporate Tax: 6 percent of income from the state

Sales and Use Tax: 5 percent combined state and local tax (4 percent state, 1 percent local)

Property Tax: No state property tax; local property taxes vary

\section{Business Incentives}

Virginia Small Business Financing Authority

Governor's Opportunity Fund

Virginia Investment Partnership Grant Fund

Enterprise Zone Tax Credits and Grants 
Tobacco Region Opportunity Fund

Workforce Services

Brownfield Local Tax Rebate Program

Community Economic Development Fund

Technology Zones

Empowerment Zone/Enterprise Community Program

\section{WASHINGTON}

\section{Basic Business Taxes}

Business and Occupation Tax: Washington imposes this tax on most businesses. It is based on gross receipts and there are few deductions available. The rate for manufacturers, distributors, and wholesalers is 0.484 percent; the rate for retailers is 0.471 percent. Services are subject to a uniform $B \& O$ tax rate of 1.5 percent.

Sales and Use Tax: Sales tax must be collected on retail sales of tangible personal property, as well as cleaning, repairing, altering, or improving real property and tangible personal property, including labor charges. Use tax is due on the value of tangible personal property used in the state on which retail sales tax has not been paid. Exemptions include groceries and prescription drugs. The state sales tax is 6.5 percent. The local rate varies from 0.5 to 2.3 percent depending on the location where services are performed.

Property Tax: Local tax with rates based on appraised value and varying by location; the average statewide effective property tax is $\$ 12.96$ per $\$ 1,000$ of assessed value.

\section{Business Incentives}

Sales and Use Tax Exemption on Machinery and Equipment

Business and Occupation Tax Credits Rural Area Business \& Occupation Tax Credit Program

Rural Area Sales and Use Tax Deferral/ Exemption Program

High-Technology Business \& Occupation Tax Credit Program

High-Technology Sales and Use Tax Deferral/Exemption Program

Warehouse Sales Tax Exemption Industrial Development Revenue Bonds Community Economic Revitalization

Board Funding

Umbrella Bonds

Development Loan Fund

Forest Products Division's Revolving Loan Fund

Washington State Job Skills Program

Employee Training

Community Empowerment Zones

Enterprise Communities

Foreign-Trade Zones

\section{WEST VIRGINIA}

\section{Basic Business Taxes}

Corporate Net Income Tax: 9 percent, based on federal taxable income, with various increasing and decreasing modifications Business Franchise Tax: 0.7 percent of net worth apportioned to state or $\$ 50$, whichever is greater

Business Registration Tax: $\$ 30$ biennially for each location in which business is conducted

Corporation Charter Tax: Various rates, from $\$ 20$ annually for capital stock of $\$ 5,000$ or less to $\$ 2,500$ annually for capital stock in excess of $\$ 15$ million

Property Tax: Varies; levied by county officials with a ceiling set by the state on the aggregate amount of levies 


\author{
Business Incentives \\ Economic Opportunity Credit \\ Manufacturing Investment Credit \\ Strategic R\&D Credit \\ Sales Tax Exemption for E-Commerce Vendors \\ High Growth Business Investment Tax Credit \\ Tourism Development Incentive \\ Tax Increment Financing \\ Corporate Headquarters Credit \\ "Five-for-Ten" Program \\ Manufacturing Sales Tax Exemption \\ Warehouse "Freeport" Tax Exemption \\ Sunny Day Fund \\ West Virginia Capital Company Credit \\ Direct and Indirect Loans \\ Industrial Revenue Bonds \\ Venture Capital \\ West Virginia Jobs Investment Trust \\ West Virginia Infrastructure and Jobs Development Council \\ West Virginia Small Business Development Center Loans \\ Linked Deposit Program \\ Governor's Guaranteed Work Force Program
}

\title{
WISCONSIN
}

\section{Basic Business Taxes}

Corporate Income Tax: 7.9 percent of net income

Sales and Use Tax: 5 percent of gross receipts from sales, leasing, or renting tangible personal property and certain services with exemptions

Property Tax: Varying rates by counties on real and tangible personal property assessed at 100 percent of full value, with exemptions for manufacturing machinery, equipment, inventories, computers, and computer equipment

\author{
Business Incentives \\ Brownfields Initiative \\ Community Development Block Grant \\ Program - Public Facilities for Economic Development \\ Development Zone Program \\ Enterprise Development Zone Program \\ Industrial Revenue Bonds \\ Minority Business Development Fund \\ Rural Economic Development Program \\ Wisconsin Development Fund: \\ - Major Economic Development Program \\ - Customized Labor Training Fund \\ - Technology Development Fund \\ Certified Capital Company Program \\ Recycling Loan Program \\ Business Employees Skills Training Awards \\ Tax Increment Financing \\ Technology Zone Program
}




\section{WYOMING}

\section{Basic Business Taxes}

Corporate Tax: No corporate or personal income tax; no inventory tax; no gross sales tax; no franchise tax

Sales and Use Tax: 4 percent of retail sales on tangible personal property and selected services; counties may levy an additional tax of up to 2 percent with voter approval.

Property Tax: Based on a de facto assessment classification, commercial and other real and personal property is assessed at 9.5 percent of market value; industrial plants assessed at 11.5 percent of current value. Mill levy rates vary among local jurisdictions but average 60 to 90 mills.

\section{Business Incentives}

Wyoming Business Council, Infrastructure, and Community Considerations:

- Community Development Block Grants

- Technical Assistance Grants

- Infrastructure Grants

- Planning Only Grants

- Job Training Grants

- Work Force Training Grants

- Wyoming Industrial Development Corporation

- Industrial Development Revenue Bonds 